\title{
Unique and shared inflammatory profiles of human brain endothelia and pericytes
}

Leon C. D. Smyth ${ }^{1,2}$, Justin Rustenhoven ${ }^{1,2}$, Thomas I.-H. Park ${ }^{1,2,3}$, Patrick Schweder ${ }^{2,4}$, Deidre Jansson ${ }^{1,2}$, Peter A. Heppner ${ }^{2,4}$, Simon J. O'Carroll ${ }^{2,3}$, Edward W. Mee ${ }^{2,4}$, Richard L. M. Faull ${ }^{2,3}$, Maurice Curtis ${ }^{2,3}$ and Mike Dragunow ${ }^{1,2^{*}}$

\begin{abstract}
Background: Pericytes and endothelial cells are critical cellular components of the blood-brain barrier (BBB) and play an important role in neuroinflammation. To date, the majority of inflammation-related studies in endothelia and pericytes have been carried out using immortalised cell lines or non-human-derived cells. Whether these are representative of primary human cells is unclear and systematic comparisons of the inflammatory responses of primary human brain-derived pericytes and endothelia has yet to be performed.
\end{abstract}

Methods: To study the effects of neuroinflammation at the BBB, primary brain endothelial cells and pericytes were isolated from human biopsy tissue. Culture purity was examined using QPCR and immunocytochemistry. Electrical cell-substrate impedance sensing (ECIS) was used to determine the barrier properties of endothelial and pericyte cultures. Using immunocytochemistry, cytometric bead array, and ECIS, we compared the responses of endothelia and pericytes to a panel of inflammatory stimuli (IL-1 $\beta$, TNFa, LPS, IFN- $\gamma$, TGF- $\beta_{1}, I L-6$, and IL-4). Secretome analysis was performed to identify unique secretions of endothelia and pericytes in response to IL-1 $\beta$.

Results: Endothelial cells were pure, moderately proliferative, retained the expression of BBB-related junctional proteins and transporters, and generated robust TEER. Both endothelia and pericytes have the same pattern of transcription factor activation in response to inflammatory stimuli but respond differently at the secretion level. Secretome analysis confirmed that endothelia and pericytes have overlapping but distinct secretome profiles in response to IL-1 $\beta$. We identified several cell-type specific responses, including G-CSF and GM-CSF (endothelialspecific), and IGFBP2 and IGFBP3 (pericyte-specific). Finally, we demonstrated that direct addition of IL-1 $\beta$, TNFa, LPS, and IL-4 contributed to the loss of endothelial barrier integrity in vitro.

Conclusions: Here, we identify important cell-type differences in the inflammatory response of brain pericytes and endothelia and provide, for the first time, a comprehensive profile of the secretions of primary human brain endothelia and pericytes which has implications for understanding how inflammation affects the cerebrovasculature.

Keywords: Neurovascular, Blood-brain barrier, Neuroinflammation, IL-1 $\beta$, SMAD2/3, IGFBP, GM-CSF

\section{Background}

Blood vessels in the brain have a unique structure, being formed by specialised endothelia that have extensive contacts with pericytes, astrocyte endfeet, microglia, and neurons [1, 2]. Unlike blood vessels in most organs, cerebral blood vessels do not allow the leakage of plasma proteins

\footnotetext{
* Correspondence: m.dragunow@auckland.ac.nz

'Department of Pharmacology and Clinical Pharmacology, The University of Auckland, Private Bag 92019, Auckland 1142, New Zealand

${ }^{2}$ Centre for Brain Research, The University of Auckland, Private Bag 92019,

Auckland 1142, New Zealand

Full list of author information is available at the end of the article
}

and entry of immune cells from the blood into the parenchyma under normal circumstances, a property known as the blood-brain barrier (BBB) [3]. The BBB is primarily formed by a continuous layer of non-fenestrated endothelia linked by tight junctions [4-7], but is also regulated by pericytes $[8,9]$, which demonstrate an exceptionally high coverage of vessels in the brain $[9,10]$. The maintenance of a functional BBB is essential to the regulation of the microenvironment in the brain parenchyma and prevents the exposure of neurons to potentially toxic blood-borne molecules like fibrinogen and haemoglobin $[11,12]$. 
Inflammation is an important process that allows the removal of pathogens and toxins; however, inflammation can be particularly damaging to the brain. The brain is fully encased by the skull, meaning that even a small degree of swelling due to inflammation can lead to damaging increases in intracranial pressure. At the cellular level, the brain possesses a limited regenerative capacity and loss of neurons as a result of unchecked inflammation cannot be fully compensated through endogenous cellular replacement [13]. Neuronal death can be caused directly by inflammatory cytokines, or through the inflammatory activation of the brain's resident immune cells, microglia $[14,15]$. It is now understood that both BBB breakdown and inflammation are widespread in neurological diseases and are hallmarks of Alzheimer's disease [16, 17], epilepsy $[18,19]$, stroke [20, 21], and multiple sclerosis [22-25].

In the brain, microglia and astrocytes are the most commonly studied neuroinflammatory cell types; however, blood vessels are another important site of cerebral inflammation [26]. The vasculature is perhaps a more significant target for inflammation in the brain than in other organs, due to the presence of the $\mathrm{BBB}$ [27]. The $\mathrm{BBB}$ has been shown to break down in inflammatory conditions $[28,29]$ and diseased states [12, 17, 23, 30-32] allowing entry of peripheral immune cells or toxic/inflammatory plasma products into the parenchyma [11]. Pericytes and endothelia therefore occupy a unique position, at the interface of the brain and the periphery, and may contribute to the propagation of systemic inflammation to the brain [29]. Conversely, vessels can be a target of neuroinflammation that has begun in the brain, with the potential to exacerbate dysfunction through opening of the BBB [33]. Brain endothelia are known to be sensitive to inflammation, secreting chemokines such as monocyte chemoattractant protein-1 (MCP-1), which draw circulating immune cells to an area of injury [34]. Inflammatory signalling in endothelia also induces the expression of cell adhesion molecules, making the vessel 'sticky' to immune cells and allowing for extravasation of peripheral immune cells into the brain parenchyma [35]. Recently, pericytes have garnered attention as mediators of inflammation in the brain, also secreting chemokines and expressing cell adhesion molecules [1, 36-38]. Interestingly, pericytes may play a unique role in immune infiltration, being able to 'instruct' immune cells following extravasation [39], assist in leukocyte crawling in the vessel [40], and alter their morphology to facilitate neutrophil extravasation [41]. Furthermore, there is mounting evidence that pericyte secretions may alter endothelial barrier function following inflammatory activation [42], as demonstrated in models of stroke [43]. Indeed, vascular clustering and pericyte reactivity is observed in diseases with an inflammatory component, such as stroke and epilepsy $[18,20]$, with migration of pericytes away from the vascular wall [19, 21], and may have implications for tissue fibrosis [44, 45].

Human brain biopsy tissue is a valuable resource for the study of neuroinflammation and aspects of human disease in pericytes and endothelia of the BBB [46, 47]. The growth of pure endothelia and pericyte cultures allows their inflammatory responses to be interrogated in isolation, providing cell-specific information. We demonstrate that endothelia retain $\mathrm{BBB}$ properties in vitro, and that barrier function is regulated strongly by inflammatory stimuli. Furthermore, we identify both distinct and overlapping immune responses between primary brain endothelia and pericytes that are important to understanding how inflammation may affect the BBB.

\section{Methods}

Tissue source

The experiments conducted here were approved by the Northern Regional Ethics Committee (New Zealand) for biopsy tissue and The University of Auckland Human Participants Ethics Committee for post-mortem brain tissue. All methods were carried out in accordance with the approved guidelines. Biopsy human brain tissue was obtained with informed written consent from the patient and family members (Additional file 1). Tissue used in this study was derived from paediatric epilepsy surgery, surgery for adult drug-refractive epilepsy, and normal brain regions resected from patients with deep tumours (Additional file 1: Table S1). This technique provided sufficient endothelial yields for experiments from as little as $0.25 \mathrm{~g}$ tissue. Cultures were also attempted from postmortem brains (Additional file 1: Table S1), however yielded too few viable endothelia for experimentation.

\section{Tissue dissociation}

The endothelial cell culture protocol was adapted to work in concert with a previously established method to generate mixed glial cultures from surgical specimens, routinely used in our laboratory [48]. Cultures of endothelial cells were attempted using autopsy specimens as well, but yielded few or no viable endothelial cells. Following collection of tissue, HBSS and meninges were removed. Tissue was then thoroughly mechanically dissociated with a sterile scalpel and enzymatically dissociated $(10 \mathrm{~mL} / \mathrm{g}$ tissue; $10 \mathrm{U} / \mathrm{mL}$ DNase I (Invitrogen, CA, USA), $2.5 \mathrm{U} / \mathrm{mL}$ papain (Worthington, NJ, USA) in Hibernate-A medium (Gibco, CA, USA)) for $15 \mathrm{~min}$ at $37{ }^{\circ} \mathrm{C}$ with agitation. The suspension was triturated, and then left to dissociate for a further $15 \mathrm{~min}$ at $37^{\circ} \mathrm{C}$ with agitation. Digestion was quenched with the addition of one volume of media, either complete DMEM as per [48] (Dulbecco's modified Eagle's media with F12 supplement (DMEM:F12; Gibco) containing 10\% FBS (Gibco, CA, USA), $1 \%$ penicillin/streptomycin (Gibco), and $1 \%$ 
GlutaMAX (Gibco)); neural stem cell medium as per [49, 50] (DMEM:F12 with 1\% B27 supplement (Gibco), $1 \%$ penicillin/streptomycin, $1 \%$ GlutaMAX); or neuronal medium as per Park et al. (In submission) (DMEM:F12 with 1\% vitamin A-containing B27 supplement (Gibco), $1 \%$ penicillin/streptomycin (Gibco), 1\% GlutaMAX (Gibco), and BDNF, NGF, NT3, GDNF, and IGF-1 (Peprotech, NJ, USA) at $40 \mathrm{ng} / \mathrm{mL}$ ). At this point, the suspension was allowed to settle and the supernatant, containing cell suspension, was passed through a 70- or 100- $\mu \mathrm{m}$ nylon strainer (Bector Dickinson, NJ, USA). The remaining debris and vessel component was triturated and passed through the strainer.

\section{Mixed glial and pericyte cultures}

Components of the suspension that passed through the strainer contain other cerebral cell types and can be cultured to obtain pericytes [48], microglia [49], neural stem cells [50], and neurons (Park et al., In submission). Here, the single cell suspension was plated into a T75 and cultured in complete DMEM and left to generate a mixed glial culture containing pericytes, astrocytes, microglia, and endothelia and otherwise treated as per [48]. At passage 2, mixed glial cultures were used as a positive control for GFAP, PU.1, and PDGFR $\beta$ immunostaining to compare isolated endothelia in Fig. 1 (Additional file 1: Table S2). Due to the proliferation of pericytes, but not other cell types in mixed glial cultures, serial passaging of mixed glial cultures yields pericyte monocultures, as we have established previously [36]. Pericyte monocultures were used as a negative control for endothelial marker immunostaining in Fig. 2. In experiments where the inflammatory response of endothelial cells and pericytes was compared, only pericyte monocultures were used (Figs. 3, 4, and 5). These were treated as previously described and pericytes used for comparison [51, 52]. Briefly, pericytes were grown in complete DMEM in T75 flasks until confluent. Pericytes were subcultured by trypsinisation ( $0.25 \%$ trypsin-EDTA; Gibco) and seeded at a density of 15,000 cells $/ \mathrm{cm}^{2}$ for most experiments and 30,000 cells $/ \mathrm{cm}^{2}$ for ECIS experiments. See Additional file 2: Table S2 for details of epilepsy-derived pericyte monocultures used.

\section{Isolation and maintenance of brain endothelial cultures}

The strainers used to obtain the aforementioned single cell suspension were placed in a sterile petri dish and strainers inverted so that debris could be washed off strainers in complete DMEM. The debris was collected and spun at $170 \times g$ for $5 \mathrm{~min}$. Media was aspirated, and the pellet was gently resuspended for in ScienCell Endothelial Cell Medium (ECM; ScienCell, CA, USA) plating into a Matrigel $^{\odot}$ (thin coating $2.5 \mu \mathrm{L} / \mathrm{cm}^{2}$; Corning, NY, USA)-coated flask as per the manufacturer's instructions
(See Table 1 for approximate plating guidelines). Vessels and debris were left to adhere overnight, before being washed gently to detach loosely adhered debris. The media was changed to puromycin $(0.5 \mu \mathrm{g} / \mathrm{mL}$; Sigma-Aldrich, MO, USA)-containing ECM. Elongated, cobblestoneshaped endothelia emerged and could be distinguished from other cell types initially present in cultures, including pericytes (large, stellate), microglia (rhomboidal, phase bright), and astrocytes (complex, thin processes). Human brain endothelial cell cultures were maintained in puromycin-containing ECM for 1-2 weeks in order to eliminate other cell types. Brain endothelia are resistant to puromycin-induced toxicity due to their ability to pump it out, and puromycin therefore selects for endothelial cells [53]. Following this, cells were grown in ECM without puromycin for the remainder of their time in culture. Subculture was achieved by detaching endothelia with StemPro ${ }^{\circ}$ Accutase ${ }^{\oplus}\left(5 \mathrm{~min}, 37^{\circ} \mathrm{C}\right.$; Gibco), and plating into new Matrige ${ }^{\circledR}$-coated plates at a density of 30,000 cells $/ \mathrm{cm}^{2}$, except for barrier studies where they were seeded at 60,000 cells $/ \mathrm{cm}^{2}$ onto collagen I-coated plates $\left(1 \mu \mathrm{g} / \mathrm{cm}^{2}\right.$; Gibco). In general, barrier studies were performed in passages 2-3, while secretion analysis was performed at passages 4-5. Endothelia can be maintained over multiple passages (Range: 3-8 passages) and are amenable to cryostorage in 90\% FBS:10\% DMSO for extended periods. In order to successfully passage endothelia multiple times, flasks should not be split at a ratio of less than 1:2.

\section{Matrige ${ }^{\circledR}$ coating of plates and flasks}

Matrige $^{\circledR}$ (Corning) was allowed to thaw on ice, before being diluted 1:80 in DMEM:F12 without any additives (Gibco) and kept on ice. Ice cold diluted Matrigel $^{\bullet}$ was added to plates at $2.5 \mu \mathrm{L}$ Matrigel $^{\oplus}$ per square centimetre of plastic and left at room temperature for at least $1 \mathrm{~h}$. Plates and flasks were then washed three times for at least $30 \mathrm{~min}$ in additive-free DMEM:F12, before this was aspirated and surfaces allowed to air-dry overnight. Plates and flasks were then sealed and kept at $4{ }^{\circ} \mathrm{C}$ for up to 3 months.

\section{Magnetic-activated cell sorting}

For initial attempts to isolate endothelia, magneticactivated cell sorting (MACS) based on CD31 expression was used (Additional file 1: Figure S1). Briefly, endothelial cells were cultured as above; however, puromycin was omitted. At the first passage, Accutase (Gibco, CA, USA) was used to dissociate cultures, before being washed in MACS buffer (1\% bovine serum albumin, $1 \mathrm{mM}$ EDTA in PBS) and Fc receptor blocking agent added, followed by addition of magnetic beadconjugated mouse IgG1 anti-human CD31 antibody (Miltenyl Biotech, Cologne, Germany) for $15 \mathrm{~min}$ at $4^{\circ}$ C. The cell suspension was washed in MACS buffer and passed through a MACS separation column, as per the 

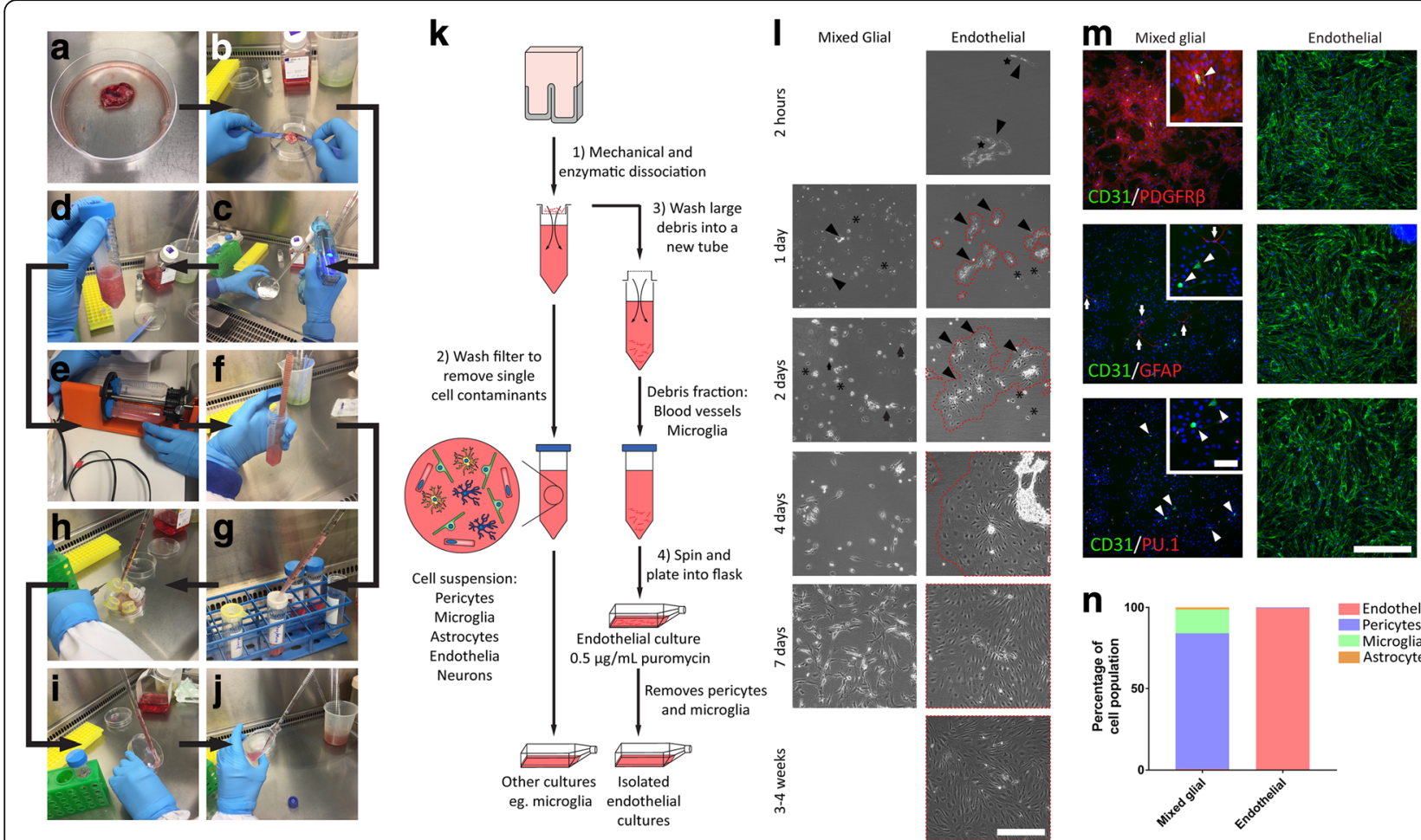

Fig. 1 Generation of pure endothelial cultures from human brain tissue. Brain tissue was cultured to generate mixed glial and endothelial cultures. Cells were fixed, and purity of cultures was assessed at passage two using immunocytochemistry. a Processing of biopsy specimens, followed by $\mathbf{b}$ mechanical and $\mathbf{c}-\mathbf{e}$ enzymatic digestion at $37^{\circ} \mathrm{C}$. Suspension was $\mathbf{f}$ triturated and $\mathbf{g}$ passed through cell strainers $\mathbf{h}$ which were washed. i Debris were collected, spun, and $\mathbf{j}$ plated onto a matrigel-coated flask. $\mathbf{k}$ Schematic of the method used to generate mixed glial (containing astrocytes/microglia/endothelia/pericytes), and isolated endothelial cultures. I Representative live images of passage 1 cultures throughout different growth stages. Arrowheads highlight blood vessels and endothelia while areas outlined in red are endothelial colonies, arrows indicate astrocytes and asterisks denote microglia. Scale bar $=200 \mu \mathrm{m}$. $\mathbf{m}$ Representative images and $\mathbf{n}$ quantification of staining for lineage markers (CD31, endothelial; PDGFRß, pericyte; GFAP, astrocyte; PU.1, microglial) in passage two mixed glial and endothelial cultures. Scale bar $=500 \mu \mathrm{m}$, inset scale bar $=100 \mu \mathrm{m}$. d Cell lineage assessment of endothelial and mixed glial cultures (mean, $n=3$ mixed glial, $n=5$ endothelial)

manufacturer's instructions to elute the negative fraction, followed by elution of the CD31-positive endothelial fraction in MACS buffer. The positive and negative fractions were spun at $170 \times g$ for $5 \mathrm{~min}$ and plated at a density of 30,000 cells $/ \mathrm{cm}^{2}$ into 96 -well plates.

\section{Cytokine treatments}

Inflammatory cytokines interleukin-1 $\beta$ (IL-1 $\beta$ ), tumour necrosis factor- $\alpha$ (TNF $\alpha)$, lipopolysaccaride (LPS), interferon- $\gamma$ (IFN- $\gamma)$, transforming growth factor- $\beta 1$ (TGF- $\left.\beta_{1}\right)$, interleukin 6 (IL-6), and interleukin 4 (IL-4) or vehicle (a mixture of the vehicles for IL- $1 \beta$, TNF $\alpha$, LPS, IFN- $\gamma$, IL-6, and IL-4 (0. $1 \%$ bovine serum albumin (BSA) in phosphate buffered saline (PBS)) and $1 \mathrm{mM}$ citric acid, pH 3 with $0.1 \% \mathrm{BSA}$, for TGF- $\beta_{1}$ ) were added as a 100 -fold dilution of a $100 \times$ stock to both pericytes and endothelia. See Table 2 for details.

\section{Immunocytochemistry (ICC)}

Cells in 96-well plates were fixed in 4\% paraformaldehyde for $15 \mathrm{~min}$ and washed with PBS with Triton ${ }^{\text {Ta }}$ X-100 (0.1\%; Sigma, MO, USA) (PBS-T). Primary antibodies, diluted appropriately in immunobuffer (PBS with $0.2 \%$ Triton $^{\text {Tw }} \mathrm{X}-100,1 \%$ goat serum (Gibco, CA, USA) and $0.04 \%$ thimerosal (Sigma, MO, USA)), were added overnight at $4{ }^{\circ} \mathrm{C}$ (See Additional file 2: Table S3 for details). The following day, secondary antibodies were added at room temperature for $3 \mathrm{~h}$. Hoechst nuclear counterstain (1 $\mu \mathrm{M}$; Hoechst 33258, Sigma, MO, USA) in Tris-NaCl-EDTA (TNE) buffer was added for $10 \mathrm{~min}$ at room temperature. For stains that were sensitive to detergent (zona occludens-1; ZO-1), $\operatorname{Triton}^{\mathrm{Th}} \mathrm{X}$ 100 was excluded until after the primary antibody incubation. Wells were then washed again and counterstained with Hoechst-33258 nuclear stain. For experiments directly comparing endothelial and pericyte inflammatory response, both endothelia and pericytes were seeded and imaged on the same plate. Images were acquired on an ImageXpress Micro XLS ${ }^{\mathrm{tm}}$ automated microscope (Molecular Devices).

\section{5-Ethynyl-2'-deoxyuridine (EdU) proliferation assay}

Proliferation was measured by 5-ethynyl-2' -deoxyuridine (10 $\mu \mathrm{M}$; Click-iT ${ }^{\bullet}$ EdU AlexaFluor 647 Imaging Kit; 

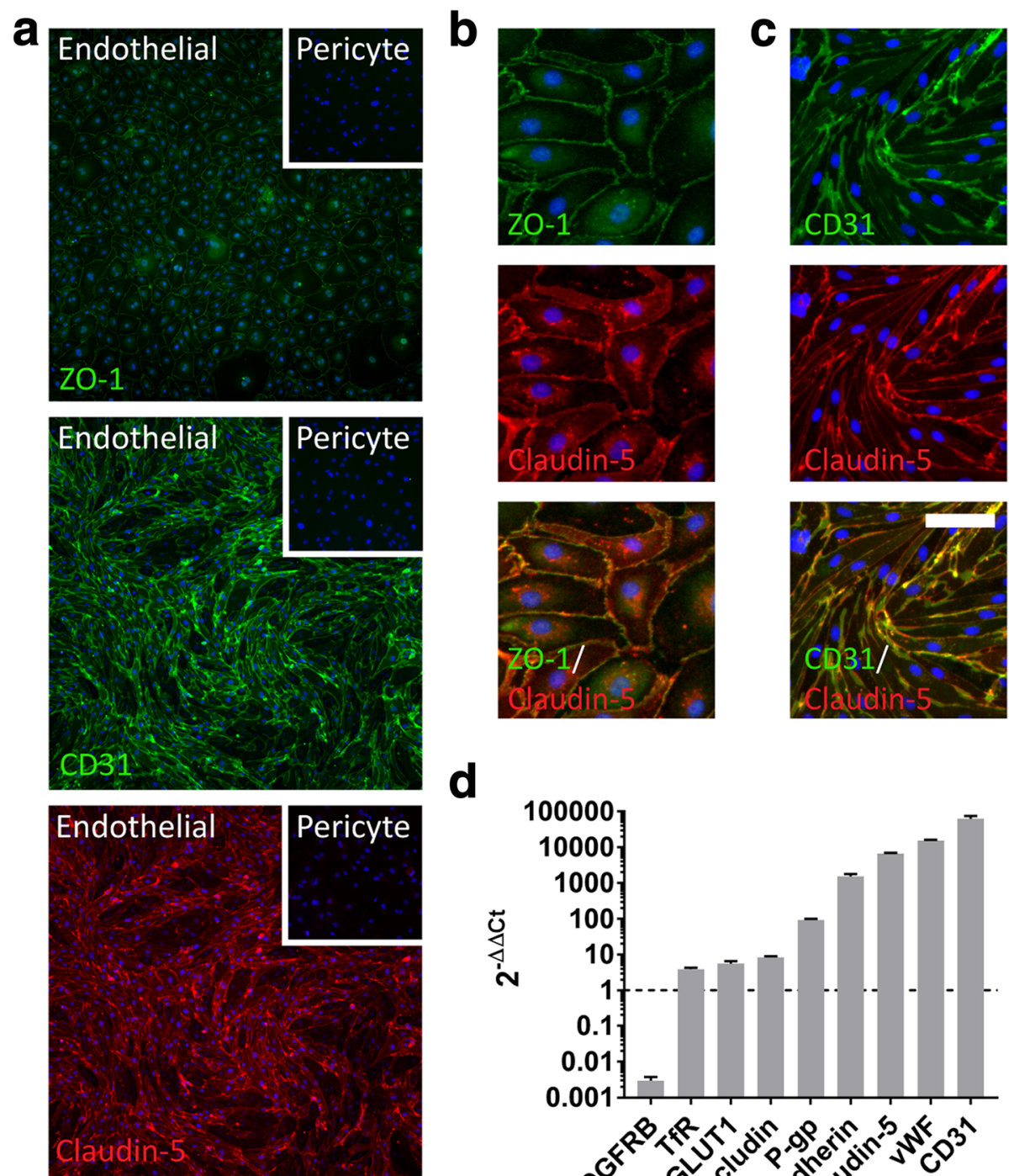

\section{d}
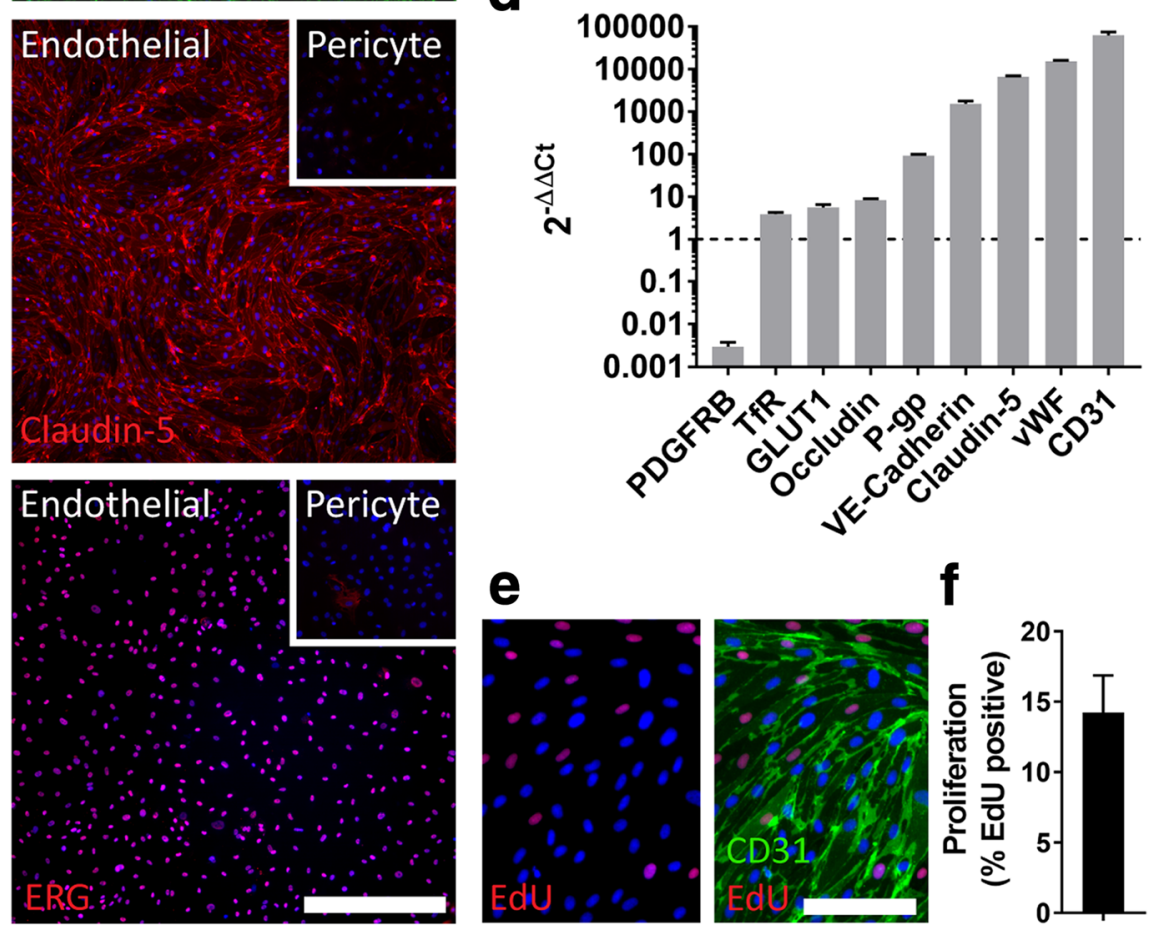

Fig. 2 Isolated endothelia are proliferative and re-establish blood-brain barrier phenotype. Endothelial and pure pericyte cultures were treated with EdU $(48 \mathrm{~h}, 10 \mu \mathrm{M})$ then fixed and stained for the junctional proteins ZO-1, claudin-5, CD31, endothelial nuclear marker ERG, and proliferation marker EdU. RNA was extracted from endothelia, and a single pure pericyte culture, and gene expression analysed by qPCR. a Representative images of immunocytochemical staining of zona occludens-1 (ZO-1), CD31, claudin-5, and ERG in endothelia and pericytes. Scale bar = 500 um. $\mathbf{b}$ High-magnification representative images of co-staining of CD31 and claudin-5, and $\mathbf{c}$ CD31 and claudin-5. Scale bar $=25 \mu \mathrm{m}$. $\mathbf{d}$ Gene expression analysis of endothelial cultures (mean $\pm \mathrm{SEM}, n=3$ ), normalised to gene expression of a single pure pericyte culture. e Representative images of EdU staining in endothelia and $\mathbf{f}$ quantification of basal proliferation over $48 \mathrm{~h}$ 


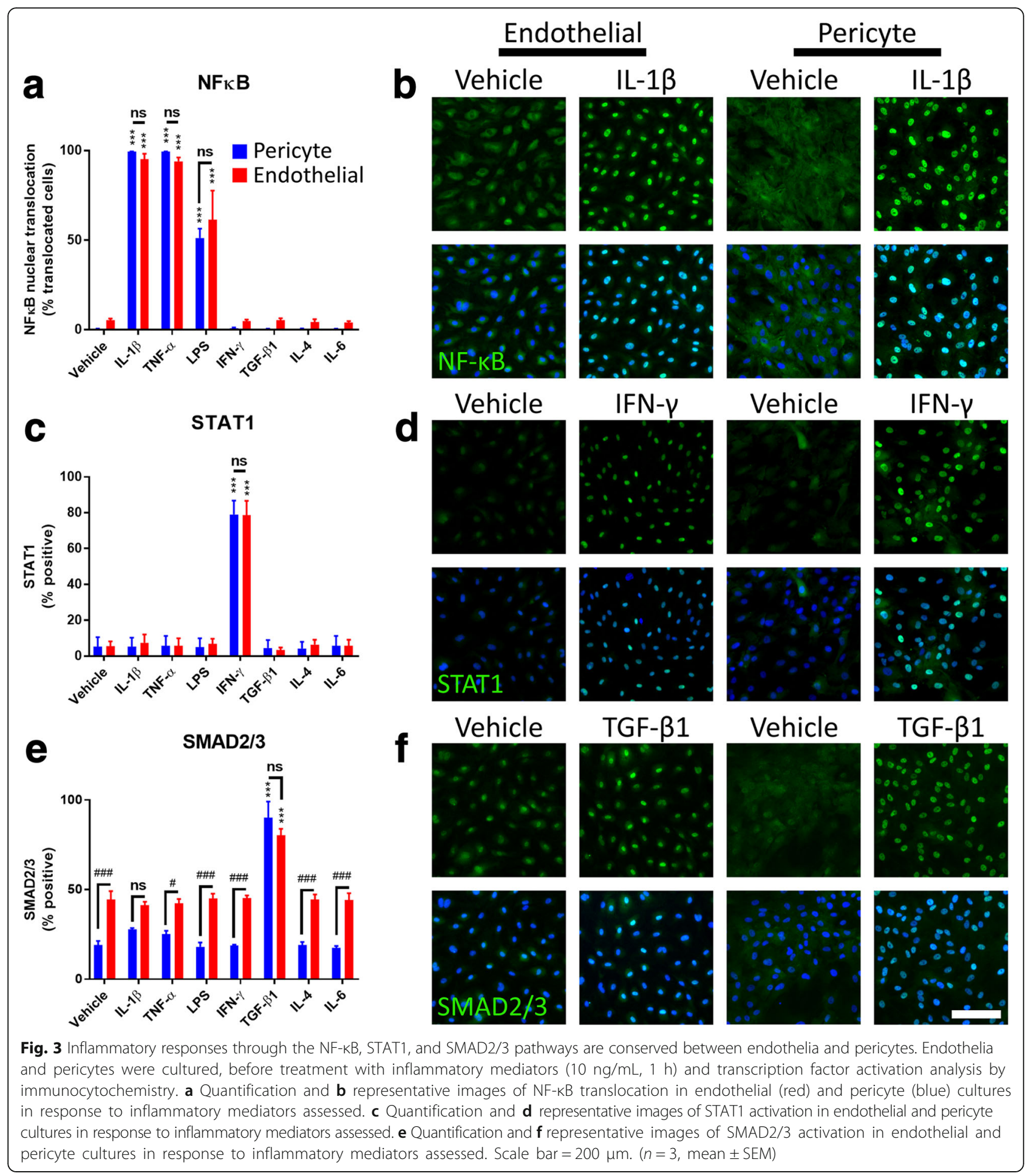

Molecular Probes, CA, USA) incorporation for $48 \mathrm{~h}$ at $37{ }^{\circ} \mathrm{C}, 5 \% \mathrm{CO}_{2}$. Fixed cells that had been immunostained, as described previously, were then washed in $3 \%$ BSA in PBS-T twice. EdU staining was visualised using the Click-iT $^{\circledast}$ AlexaFluor $^{\text {Ts }} 647$ kit as per the manufacturer's instructions. Nuclei positive for EdU were scored using MetaXpress ${ }^{\text {TM }}$ version 5.3.04 (Molecular Devices) analysis software.

\section{Image analysis}

Quantification of cell populations was performed by immunocytochemistry with well-characterised lineage markers. 


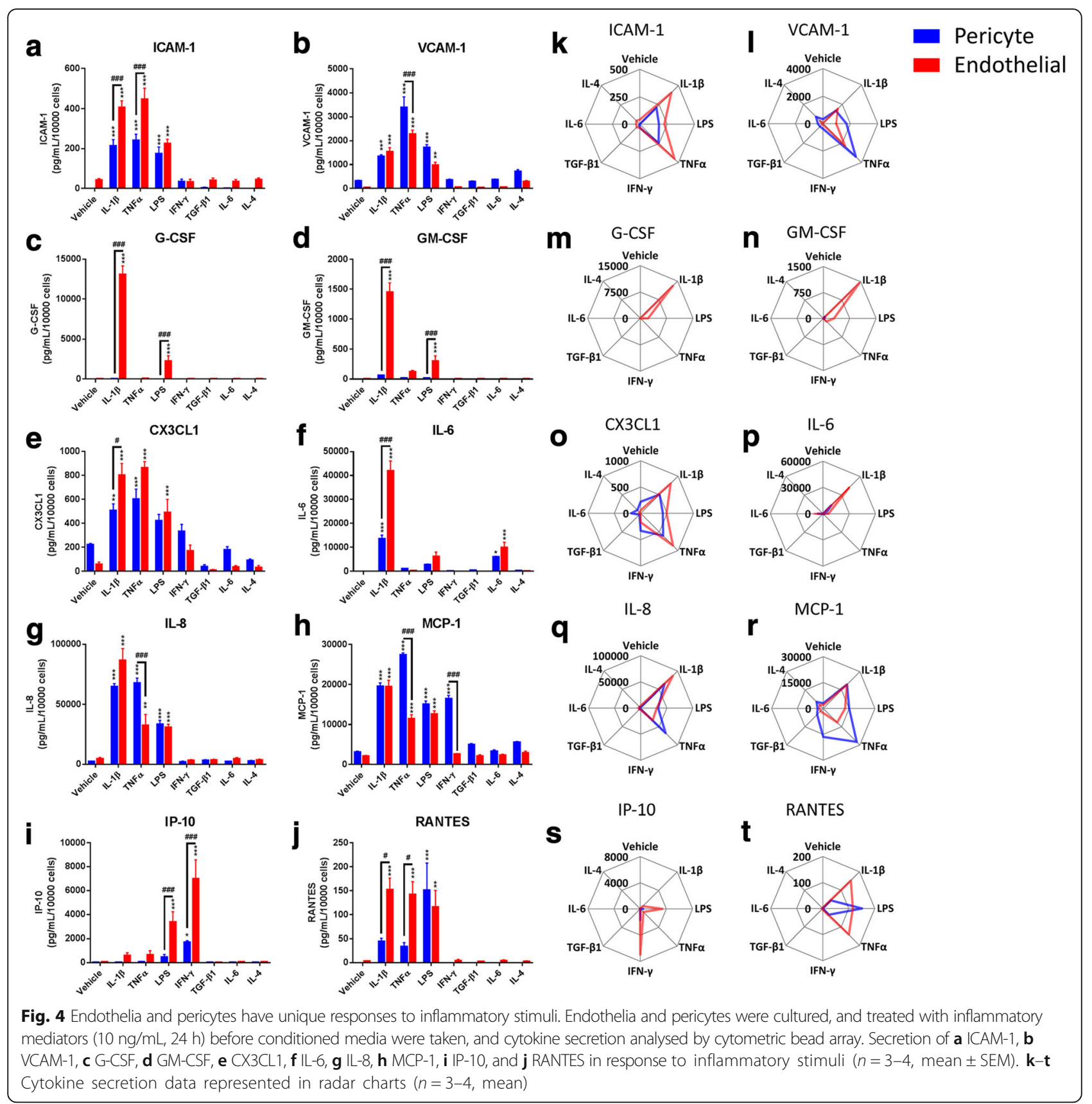

Nuclei positive for PU.1 were designated as microglial using MetaXpress $^{\mathrm{TM}}$ software, while in mixed glial cultures, CD31positive cells lacking PU.1-positive nuclei were designated as endothelia. Remaining cell populations could not be accurately scored by automated analysis and were therefore counted manually. Glial fibrillary acidic protein (GFAP)positive cells were determined to be astrocytes. The remaining cells were found to be platelet derived growth factor receptor- $\beta$ (PDGFR $\beta$ )-positive and designated as pericytes. In endothelial cultures, the remainder of GFAPnegative, PU.1-negative, and PDGFR $\beta$-negative cells were designated endothelia. Quantification of intercellular cell adhesion molecule-1 (ICAM1) and MCP-1 intensity was performed by setting a low threshold and measuring the integrated intensity of the thresholded pixels, relative to the cell number. Quantification of signal transducer and activator of transcription-1 (STAT1) and similar to mothers against dodecapentaplegic-2/3 (SMAD2/3) was performed by setting a high threshold and scoring the percentage of Hoechst-positive nuclei above the threshold value. Quantification of nuclear factor kappa-light-chain-enhancer of activated B cells p65 (NF-kB) translocation was performed using the translocation assay built in to MetaXpress ${ }^{\mathrm{TM}}$ software. 


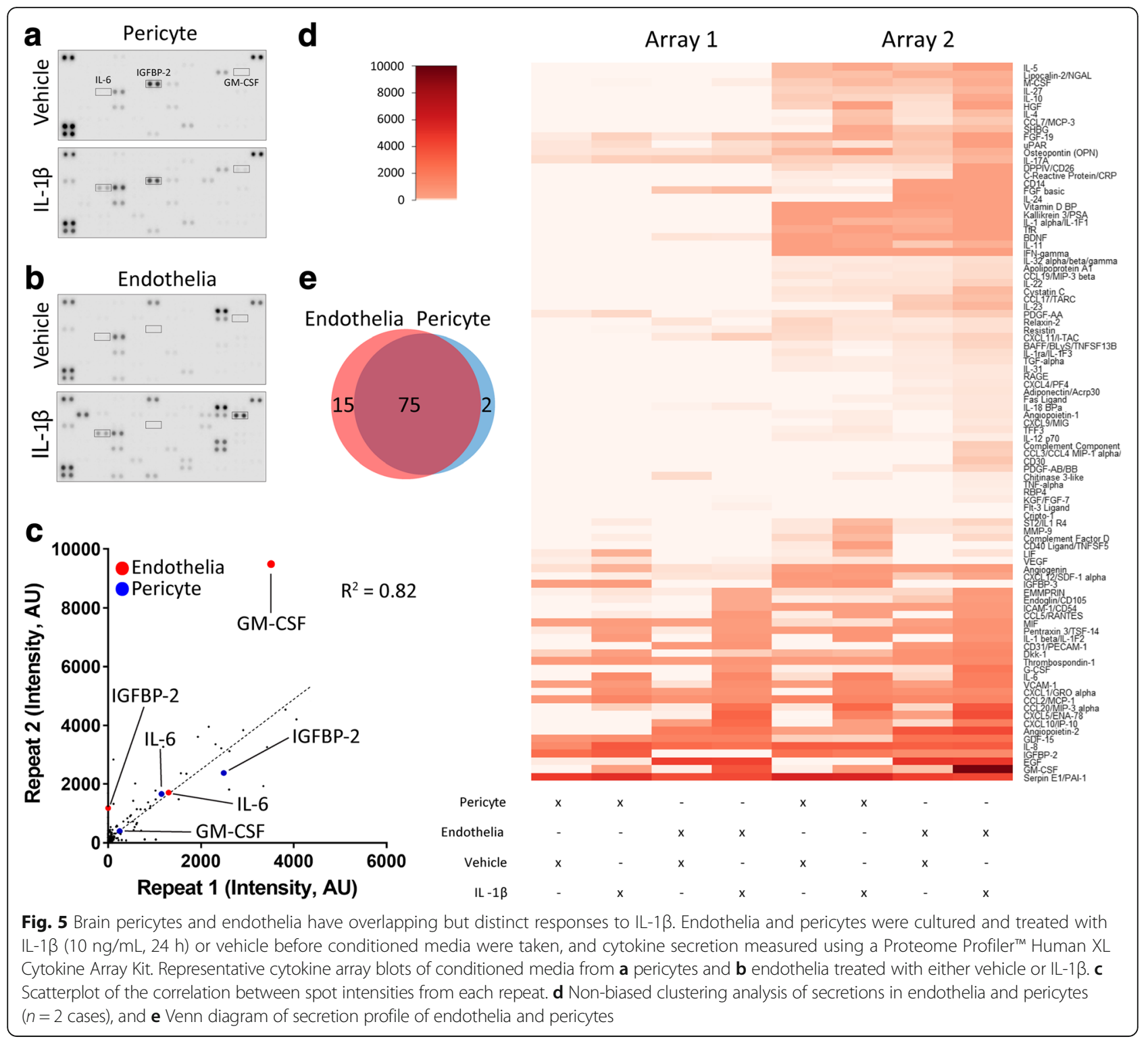

Quantitative real-time polymerase chain reaction (qPCR) Total RNA was extracted from endothelia or pericytes grown in a 12-well plate using the Ambion RNA Micro-scale extraction kit (Ambion, CA, USA) following the manufacturer's instructions. For complementary DNA (cDNA) synthesis, 500 ng total cDNA was made

Table 1 Approximate guidelines for culture area for a given mass of tissue

\begin{tabular}{ll}
\hline Tissue weight & Culture flask \\
\hline Less than $0.5 \mathrm{~g}$ & 12-well plate \\
$0.5-2 \mathrm{~g}$ & $9 \mathrm{~cm}^{2}$ Petri dish \\
$2-10 \mathrm{~g}$ & $\mathrm{~T} 25$ \\
More than $10 \mathrm{~g}$ & $\mathrm{~T} 75$ \\
\hline
\end{tabular}

per sample. RNA was added to each reaction mix accordingly and diluted to give the same volume, before deoxyribonuclease I (DNase I) from the RQ1 RNasefree DNase kit (Promega, WI. USA) with $1 \mu \mathrm{g}$ DNase added per $1 \mu \mathrm{g}$ RNA. The Superscript III First-Strand Synthesis kit (Life Technologies, CA, USA) was used for cDNA synthesis. Quantitative real-time PCR was performed using Platinum SYBR Green qPCR SuperMix-UDG with Rox (Life Technologies, CA, USA) on a 7900HT Fast Real-Time PCR system (Applied Biosystems, Life Technologies, CA, USA) (see Additional file 1: Table S4 for primer details). Relative gene expression was graphed as fold enrichment using the $2^{-\Delta \Delta \mathrm{Ct}}$ method compared to RNA obtained from a single culture of pure pericytes [29]. 
Table 2 Inflammatory stimuli panel used, concentrations, treatment times, and suppliers

\begin{tabular}{|c|c|c|c|c|}
\hline Inflammatory stimulus & Concentration (ng/mL) & Incubation & Supplier & Catalogue \\
\hline $\mathrm{IL}-1 \beta$ & 10 & $1 \mathrm{~h}, 24 \mathrm{~h}$ & PeproTech, NJ, USA & 200-01B \\
\hline TNFa & 10 & $1 \mathrm{~h}, 24 \mathrm{~h}$ & PeproTech, NJ, USA & $300-01 \mathrm{~A}$ \\
\hline LPS (E. coli, 026:B6) & 10 & $1 \mathrm{~h}, 24 \mathrm{~h}$ & Sigma, MO, USA & L4391 \\
\hline $\mathrm{IFN}-\gamma$ & 10 & $1 \mathrm{~h}, 24 \mathrm{~h}$ & R\&D Systems, MN, USA & $285-I F$ \\
\hline TGF- $\beta_{1}$ & 10 & $1 \mathrm{~h}, 24 \mathrm{~h}$ & PeproTech, NJ, USA & $100-21$ \\
\hline IL-6 & 10 & $1 \mathrm{~h}, 24 \mathrm{~h}$ & PeproTech, NJ, USA & $200-06$ \\
\hline $\mid \mathrm{L}-4$ & 10 & $1 \mathrm{~h}, 24 \mathrm{~h}$ & PeproTech, NJ, USA & 200-04 \\
\hline
\end{tabular}

\section{Electrical cell-substrate impedance sensing (ECIS) for barrier analysis}

Electrical cell-substrate impedance sensing (ECIS) is a technique used to measure the resistance to flow of current across a monolayer of cells at multiple frequencies in real time. To determine the barrier properties of isolated human brain endothelial cells or pericytes, experiments were performed on collagen I-coated $(1 \mu \mathrm{g} /$ $\mathrm{cm}^{2}$; Gibco, CA, USA) ECIS 96W20idf plates $\left(0.33 \mathrm{~cm}^{2}\right.$ well; Applied BioPhysics, NY, USA) for the ECIS Z instrument (Applied BioPhysics, NY, USA). Endothelia were then seeded at 60,000 cells $/ \mathrm{cm}^{2}$ and generated raw impedance values of approximately 2000-2500 $\Omega$ when measured at $4000 \mathrm{~Hz}$. Cells were cultured until transendothelial electrical resistance (TEER) had plateaued (between 96 and $120 \mathrm{~h}$ post plating) before treatments were performed. Barrier resistance values were obtained using ECIS software (Version 1.2.123.0; Applied Biophysics, NY, USA), using the modelling method described by Giaever and Keese [54], and applied to endothelial barrier measurements elsewhere [55]. Briefly, the changes in impedance relative to a cellfree, media-containing well were measured and used to determine the components of impedance defined by cell shape/granularity (capacitance, measured in $\mathrm{nF}$ ), cellsubstrate contacts (alpha, measured in $\Omega^{-1 / 2} / \mathrm{cm}$ ), and cell-cell contacts $\left(R_{b}\right.$, given as TEER in results, measured in $\Omega \mathrm{cm}^{2}$ ). It should be noted that ECIS does not detect comparable levels of resistance to those generated by an EVOM voltohmmeter, which is commonly used to measure TEER, where the units for are in $\Omega \mathrm{cm}^{-2}$, rather than $\Omega \mathrm{cm}^{2}$; however, the measurements represent similar properties of the monolayer.

\section{Cytometric bead array (CBA)}

Conditioned media samples from endothelial and pericyte cases were spun at $160 \times g$ for $5 \mathrm{~min}$ and the supernatant collected and stored at $-20^{\circ} \mathrm{C}$. The concentration of cytokines was measured using a cytometric bead array (CBA; BD Biosciences, CA, USA) as per manufacturer's instructions (see Table 3 for CBA kit details). CBA samples were run on an Accuri C6 flow cytometer (BD Biosciences, CA,
USA). Data were analysed using FCAP-array software (version 3.1; BD Biosciences, CA, USA) to convert fluorescent intensity values to concentrations using an 11-point standard curve $(0-10,000 \mathrm{pg} / \mathrm{mL})$ and normalised to cell number as described previously $[52,56]$.

\section{Secretome profiler analysis}

Conditioned media samples from two independent endothelial and pericyte cases treated with either vehicle or IL-1 $\beta$ (10 $\mathrm{ng} / \mathrm{mL}, 24 \mathrm{~h}$ ) were spun at $160 \times g$ for $5 \mathrm{~min}$, the supernatant was collected and stored at $-20{ }^{\circ} \mathrm{C}$. Conditioned media was assayed using the Proteome Profiler $^{\mathrm{rm}}$ Human XL Cytokine Array Kit as per the manufacturer's instructions (R\&D Systems, MN, USA). Briefly, membranes spotted with antibodies were incubated with conditioned media overnight at $4{ }^{\circ} \mathrm{C}$. The following day, detection antibody cocktail was added for $1 \mathrm{~h}$ at room temperature, before visualisation using chemiluminescence. Images were acquired using the Li-COR Odyssey $\mathrm{FC}^{\ominus}$ imaging system, and spot intensity was quantified using ImageJ and normalised to the reference spots.

\section{Statistical analysis}

All experiments were performed in at least three independent cases. In general, data are expressed as mean \pm standard error of mean (SEM) from at least three independent experiments. Data visualisation and statistical hypothesis testing was performed using GraphPad Prism $^{\circ}$ Version 7.00. Two-way analysis of variance (ANOVA) was used when comparing cell type response across a number of stimuli with Tukey's post hoc adjustment for multiple comparisons, while one-way ANOVA with Dunnett's multiple comparison adjustment was used when comparing changes in TEER in response to stimuli. For heatmap generation, including unbiased hierarchical clustering, the heatmap. 2 function was utilised in ' $R$ ' software.

\section{Results}

Determination of endothelial purity

After having obtained large debris from tissue dissociation (Fig. 1a-k), blood vessels containing viable endothelia were 
Table 3 CBA kits and specifications used in these studies

\begin{tabular}{lll}
\hline Antibody & Cat no. & Bead position \\
\hline sCD54/ICAM-1 (intercellular adhesion molecule-1) & 560269 & A4 \\
SCD106/NCAM-1 (vascular cell adhesion molecule-1) & 560427 & D6 \\
Fractalkine (CX3CL1) & 560265 & C6 \\
G-CSF (granulocyte-colony stimulating factor) & 558326 & C8 \\
GM-CSF (granulocyte macrophage-colony stimulating factor) & 558335 & C9 \\
IL-6 (interleukin-6) & 558276 & A7 \\
IL-8 (interleukin-8) & 558277 & A9 \\
IP-10 (interferon gamma-induced protein-10) & 558280 & B5 \\
MCP-1 (monocyte chemoattractant protein-1) & 558287 & D8 \\
RANTES (regulated on activation, normal T cell expressed and secreted) & 558324 & D4 \\
\hline
\end{tabular}

isolated due to their ability to stick to the Matrigel ${ }^{\circ}$-coated plastic. Endothelia were seen to emerge from vessels within $24 \mathrm{~h}$ (Fig. 1i). Visual inspection of cultures indicated that although microglia (Fig. 1i, asterisks) and pericytes (Fig. 1i, stars-only observed attached to vessels) were present early in endothelial cultures, they were eliminated within a week due to the toxicity of puromycin. Earlier attempts at isolating endothelia by cell sorting, but without puromycin, had a high degree of pericyte contamination (Additional file 1: Figure S1), and so it is recommended that puromycin treatment be continued for an additional week, and only stopped 1 or 2 days prior to the first passage. Endothelial cultures have a different morphology to mixed glial cultures, with a cobblestone monolayer of spindle-shaped cells (Fig. 1i; endothelial colonies outlined in red). On the other hand, mixed glial cultures contained astrocytes (Fig. 1i, arrows), microglia (asterisks), and pericytes (stellate, phase dark cells, prominent 1 week post plating). The purity of cultures was assessed by staining for markers of endothelia (CD31), microglia (PU.1), astrocytes (GFAP), and pericytes (PDGFR $\beta)$. The purity of endothelial cultures was determined to be greater than $99 \%$ (Fig. $1 \mathrm{~m}, \mathrm{n}$ ). In only one culture, a small population of contaminating pericytes was observed, while no microglia or astrocytes were present. In mixed glial cultures, a population of CD31-positive cells were seen, albeit with weak CD31 staining; however, these were predominantly PU.1-positive and thus categorised as microglia. CD31-positive and PU.1-negative cells were also seen in mixed cultures and denoted as endothelia, though this comprised less than $1 \%$ of the population (Fig. 1m, n).

\section{Isolated endothelia are proliferative and re-establish blood-brain barrier phenotype}

Brain endothelial cells are notable for their high expression of tight and adherens junction proteins, and transporters, and these are of considerable interest in the study of the BBB [4]. Thus, we assessed the presence of the tight junction proteins $\mathrm{ZO}-1$ and claudin-5, along with the adherens junction protein CD31, and endothelial nuclear marker ETS-related gene (ERG). All isolated endothelial cultures expressed these proteins, and staining was not present in negative control pericyte cultures (Fig. 2a). Staining patterns also indicated that ZO-1 was expressed at the junctions of cells, alongside claudin-5 staining (Fig. 2b). Likewise, CD31 expression was higher at the borders of cells, but more widely distributed across endothelia (Fig. 2c). In addition, qPCR studies revealed that genes encoding junctional proteins claudin-5, CD31, occludin, vascular endothelial cadherin (VE-cadherin), transporters glucose transporter-1 (GLUT-1), transferrin receptor (TfR), and P-glycoprotein (P-gp) and endothelial-specific von Willebrand Factor (vWF) were enriched in endothelial cultures, relative to pure pericyte cultures (Fig. 2d). Endothelial expression of the gene encoding the pericyte-specific protein for PDGFR $\beta$ was also 1000 -fold lower than pericyte cultures, indicating that cultures have minimal pericyte contamination. We also observed that endothelia are proliferative in vitro, as shown by EdUincorporation (Fig. 2e, f), and this can be increased with VEGF-A treatment (Additional file 1: Figure S2).

\section{Inflammatory responses through the NF-кB, STAT1, and SMAD2/3 pathways are conserved between endothelia and pericytes}

We assessed the response of endothelia and pericytes to a panel of immune mediators (IL-1 $\beta$, TNF $\alpha$, LPS, IFN- $\gamma$, TGF- $\beta_{1}$, IL-6, and IL-4) by examining the activation of the transcription factors NF-kB, STAT1, and SMAD2/3 after $1 \mathrm{~h}$ of treatment and the immunostaining of ICAM-1 and MCP-1 after $24 \mathrm{~h}$ of treatment. Treatment with IL-1 $\beta$, TNF $\alpha$, and LPS caused translocation of NF- $\kappa B$ to the nucleus, with no significant differences observed between endothelia and pericytes (Fig. 3a, b). IFN- $\gamma$ caused the translocation of STAT1 to the nucleus, with no significant differences observed between the cell types (Fig. 3c, d). SMAD2/3 translocation occurred in response to TGF- $\beta_{1}$ stimulation in pericytes and endothelial cells, although endothelial cells displayed higher basal nuclear SMAD2/3 
than pericytes (Fig. 3e, f). No changes in transcription factor localisation were observed following stimulation with IL-4 or IL-6. Representative images from all conditions are given in Additional file 1: Figure S3.

\section{Endothelia and pericytes have differential secretion profiles in response to immune stimuli}

Using cytometric bead array (CBA), we tested the secretions of soluble ICAM-1 (Fig. 4a, k), soluble VCAM-1 (Fig. 4b, i), G-CSF (Fig. 4c, m), GM-CSF (Fig. 4d, n), CX3CL1 (Fig. 4e, o), IL-6 (Fig. 4f, p), IL-8 (Fig. 4g, q), MCP-1 (Fig. 4h, r), IP-10 (Fig. 4i, s), and RANTES (Fig. 4j, t) from endothelia and pericytes in response to the inflammatory panel. Both endothelia and pericytes have a similar response profile to the immune stimulus panel, with slightly higher levels of ICAM-1 secreted by endothelia in response to IL- $1 \beta$ and TNF $\alpha$. We also detected soluble ICAM-1 in vehicle-treated endothelia, but not pericytes, consistent with ICC data (Additional file 1: Figure S4). On the other hand, CX3CL1 and VCAM-1 were basally secreted at higher levels in pericytes compared to endothelia, but regulated similarly in both endothelia and pericytes in response to the inflammatory stimuli (Fig. 4b, e, i, o). Pericyte secretion of CX3CL1 was also suppressed in response to TGF- $\beta_{1}$ and IL-4 (Fig. 4e, o). Both G-CSF and GM-CSF had similar secretion patterns, being strongly induced in endothelia, but not pericytes (Fig. 4c, d, m, n). Interestingly, in endothelia, IL-1 $\beta$ induced 5-10-fold more G-CSF and GM-CSF than the next strongest inducer, LPS. Both pericytes and endothelial cells secreted IL- 6 in response to IL- $1 \beta$ stimulation, with endothelia demonstrating a stronger induction than pericytes (Fig. 4f, p). While the clearest induction of IL-6 occurred in response to IL-1 $\beta$, it was also induced in both endothelia and pericytes in response to TNF $\alpha$ and LPS. IL-8 secretion was strongly induced by IL- $1 \beta$, TNF $\alpha$, and LPS in both endothelia and pericytes, though endothelial secretion of IL-8 in response to TNF $\alpha$ was weaker than pericytes (Fig. 4g, q). Similar levels of RANTES secretion were observed in response to LPS in both endothelia and pericytes, although endothelia secreted greater levels in response to IL- $1 \beta$ and TNF $\alpha$ (Fig. $4 \mathrm{j}, \mathrm{t}$ ). Interestingly, IL-4 induced a greater degree of VCAM-1 and MCP-1 secretion in pericytes than endothelia (Fig. 4h, r). Likewise, pericytes secreted higher concentrations of MCP-1 and ICAM- 1 in response to IFN- $\gamma$ than endothelia (Fig. 4a, k, h, r); however, endothelia secreted greater levels of IL-6 and IP-10 than pericytes (Fig. 4p, s). For a full summary of responses, see Table 4 .

\section{Endothelia and pericytes have overlapping but distinct secretions in response to IL-1 $\beta$ stimulation}

Corroborating CBA and immunocytochemistry data, secretions in endothelial and pericyte conditioned media were found to be strongly altered by IL-1 $\beta$ treatment. Both cell types demonstrated induction of a wide range of inflammatory mediators, as measured by secretome profiler array (Fig. 5a, b, d). The majority of the secretions assessed here are similar between the two cell types, with 75 secretions shared (Fig. 5d). There were 15 unique endothelial secretions including soluble CD31, the marker for endothelial cells used above (Fig. 5e). We also identified the secretion of two unique pericyte secretions, insulin-like growth factor binding protein-3 (IGFBP-3) and CD40L, the expression of which have been shown in pericytes and smooth muscle cells previously [56, 57] (Fig. 5e). Interestingly, the IGF-1 binding proteins IGFBP-2 and IGFBP-3 are highly expressed by pericytes, but not endothelia. This experiment was performed twice across two different cases; however, there was a high degree of consistency between the two sets of results $\left(R^{2}=0.82\right.$; Fig. $\left.5 \mathrm{c}\right)$. An additional file provides intensity measures for all cytokines using secretome profiler arrays (Additional file 2).

\section{Endothelial barrier integrity is strongly reduced by inflammatory stimuli}

Inflammation is a critical regulator of the BBB in vivo, so continuous measurement of TEER in primary brain endothelia and pericytes using ECIS was performed to assess functional barrier integrity, alongside immunocytochemistry to test if this was accompanied by a reorganisation of tight junctions. Primary endothelial cells generated consistently high TEER, with maximal TEER between 35 and $55 \Omega \mathrm{cm}^{-2}$ with raw impedance of approximately $2500 \Omega$ (Additional file 1: Figure S5), unlike pericytes (range 0.1$1 \Omega \mathrm{cm}^{-2}$, raw impedance approximately $1000 \Omega$ ) where barrier resistance was not a large component of the resistance to current (Fig. 6a, b). Measurements indicated that TEER plateaued after day 4 (Fig. $6 \mathrm{~b}$ ). The TEER of primary brain endothelial cultures was rapidly reduced by between 60 and $75 \%$ following application of IL-1 $\beta$, TNF $\alpha$, LPS, and IL-4 (Fig. 6d, e, g, i, j), with IL-4 and LPS-treated cells showing a rebound effect. We found that treatment of endothelia, but not pericytes, with IL- $1 \beta$ and TNF $\alpha$ resulted in toxicity (Additional file 1: Figure S4). Treatment with TGF- $\beta_{1}$ also reduced TEER by approximately $50 \%$ (Fig. 6d, h). Neither IFN- $\gamma$ nor IL-6 had any significant effect on TEER (Fig. 6d, f, k). These data were reinforced by claudin- 5 staining which revealed a reorganisation of tight junctions to granules in cells treated with IL-1 $\beta, T N F \alpha$, and LPS (Fig. 6c). In cells treated with LPS and TGF- $\beta_{1}$, discontinuous unsealed claudin-5 staining was present, while in IL-4-treated endothelia claudin-5-positive tight junctions appeared to have more diffuse staining (Fig. 6c). In TNF $\alpha$ and IL-4-treated endothelia, there was also a notable change in cell morphology to more spindleshaped and more rounded, respectively (Fig. 6c). 
Table 4 Summary of endothelial and pericyte secretions in response to inflammatory stimuli used in this study

\begin{tabular}{|c|c|c|c|c|c|c|c|c|c|c|c|c|c|c|c|c|c|c|c|c|}
\hline & \multicolumn{2}{|l|}{ ICAM-1 } & \multicolumn{2}{|c|}{ VCAM-1 } & \multicolumn{2}{|c|}{ CX3CL1 } & \multicolumn{2}{|c|}{ GM-CSF } & \multicolumn{2}{|l|}{ G-CSF } & \multicolumn{2}{|l|}{ IL-6 } & \multicolumn{2}{|l|}{ IL-8 } & \multicolumn{2}{|l|}{ IP-10 } & \multicolumn{2}{|c|}{ MCP-1 } & \multicolumn{2}{|c|}{ RANTES } \\
\hline & Endo & Peri & Endo & Peri & Endo & Peri & Endo & Peri & Endo & Peri & Endo & Peri & Endo & Peri & Endo & Peri & Endo & Peri & Endo & Peri \\
\hline Vehicle & + & - & - & + & - & ++ & - & - & - & - & - & - & + & + & - & - & + & + & - & - \\
\hline $\mathbb{I L}-1 \beta$ & ++++ & +++ & ++ & ++ & ++++ & +++ & ++++ & + & ++++ & - & ++++ & +++ & ++++ & ++++ & + & - & +++ & +++ & ++ & + \\
\hline TNFa & ++++ & +++ & +++ & ++++ & ++++ & +++ & + & - & + & - & + & ++ & ++ & ++++ & + & - & +++ & ++++ & + & + \\
\hline LPS & +++ & +++ & ++ & +++ & +++ & +++ & ++ & - & ++ & - & +++ & ++ & +++ & +++ & +++ & + & +++ & +++ & ++ & ++ \\
\hline IFN- $\gamma$ & + & + & - & + & + & ++ & - & - & - & - & - & + & + & + & ++++ & ++ & + & +++ & - & - \\
\hline TGF- $\beta_{1}$ & + & - & - & + & - & - & - & - & - & - & - & + & + & + & - & - & + & + & - & - \\
\hline IL-6 & + & - & - & + & - & ++ & - & - & - & - & +++ & +++ & + & + & - & - & + & + & - & - \\
\hline IL-4 & + & - & + & ++ & - & + & - & - & - & - & - & + & + & + & - & - & + & ++ & - & - \\
\hline
\end{tabular}

\section{Discussion}

Here, primary brain endothelial and pericyte cultures were used to study inflammatory processes at the BBB. The BBB is a critical target of central nervous system inflammation, and we show overlapping, but distinct, responses of two key cell types in the BBB, endothelia, and pericytes. Importantly, the protocol used to derive endothelial cells was adapted to work in concert with other brain cell culture protocols from our laboratory [48-50], without requiring additional tissue. While tissue was derived from diseases that have a strong neuroinflammatory and neurovascular component $[18,19]$, we observed that a consistent phenotype and response profile was maintained, as has been reported in our pericyte cultures previously $[36,58,59]$. Reinforcing this is the observation that markers of inflammatory activation in both cell types were low or absent under control conditions. Likewise, in endothelial cells, despite the derivation of cells from numerous tissue sources, consistent responses and a robust $\mathrm{BBB}$ phenotype were observed, with no obvious patterns associated with diseases.

Examining BBB properties of endothelia in vitro revealed that many of the inflammatory stimuli examined had detrimental effects on TEER. As expected, endothelia, but not pericytes, formed strong enough cell-cell contacts to generate robust TEER, with pericytes generating approximately $0.2 \Omega \mathrm{cm}^{-2}$ of TEER, compared to in excess of $40 \Omega \mathrm{cm}^{-2}$ in endothelia. Due to the type of ECIS arrays used, all treatments were added to the in vitro equivalent of the luminal side of endothelia, mimicking blood-borne inflammatory signals. Signalling through the NF-kB pathway by IL-1 $\beta$, TNF $\alpha$, and LPS caused a rapid reduction in TEER; however, there is a recovery following LPS stimulation. At the concentrations of IL-1 $\beta$ and TNF- $\alpha$ used, toxicity to endothelia, but not pericytes, was observed by a reduction in cell number. This toxicity likely accounts for the prolonged loss of barrier integrity as a result of IL- $1 \beta$ and TNF $\alpha$ treatment. However, the rapid onset of the IL- $1 \beta$ and TNF $\alpha$ effects cannot be explained solely by toxicity. Stimulation with IL-4 also led to loss of barrier integrity, indicating that, despite having an anti-inflammatory function, its presence is also detrimental to the BBB, something that has not been observed previously. This is a clear demonstration that antiinflammatory actions of cytokines are not necessarily synonymous to positive effects on the BBB. Stimulation of endothelia with TGF- $\beta_{1}$ also reduced barrier integrity; however, this was weaker than the activators of NF- $\mathrm{KB}$, and IL-4. Overall, these results indicate that inflammation with its genesis in the periphery or the brain can drive $\mathrm{BBB}$ opening through a number of different cytokines. Indeed, these data provide insight into the connection between inflammation and BBB breakdown in diseases such as epilepsy [18, 19], multiple sclerosis [24, 25], and Alzheimer's disease [60] (Fig. 7).

Unsurprisingly, the responses of both endothelia and pericytes to the immune stimulus panel were similar, indicating a concerted response to inflammatory stimuli. While other studies have examined endothelial [61-63] and pericyte $[36,37]$ responses to a limited panel of stimuli, this is the first direct comparison of primary human brain endothelial and pericyte inflammatory responses to such a wide range of stimuli, and in such detail. Despite the large overlap in responses, we found that the effects of IL- 4 and TGF- $\beta_{1}$ on pericyte secretions were stronger than on endothelia. In pericytes, both IL- 4 and TGF- $\beta_{1}$ upregulated IL- 6 and downregulated CX3CL1, but had opposing effects on MCP-1 and VCAM-1. This corroborates previous findings from our group, indicating that TGF- $\beta_{1}$ activates inflammatory processes in pericytes [56]. The suppression of CX3CL1 and induction of MCP-1, IL-6, and VCAM-1 in response to IL-4 suggest that its actions may enhance pericyte inflammatory signals, in contrast with its well-known antiinflammatory effects on immune cells [64]. We did not observe the activation of NF- $\mathrm{B}$, STAT1, or SMAD2/3 pathways by IL-4, though it is reported to predominantly act through STAT5 [65], which is likely to be responsible for the changes to secretions and barrier function of cells that was observed. Interestingly, IL-6 did not 

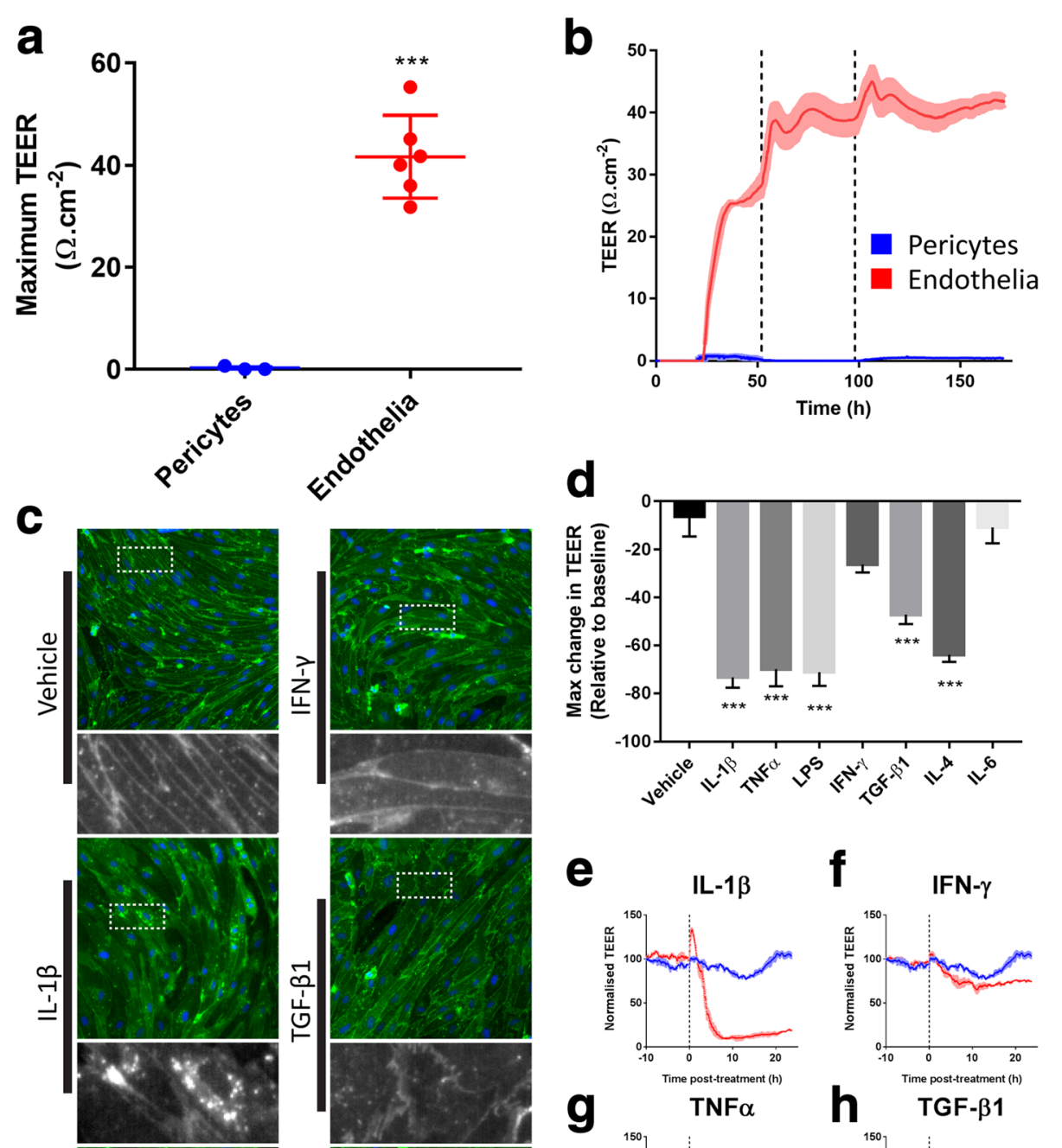

f $\quad$ IFN- $\gamma$
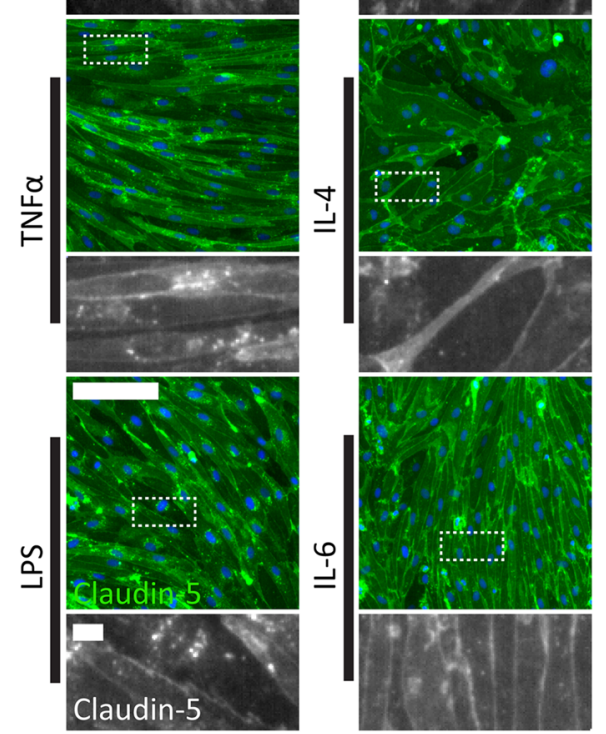

9
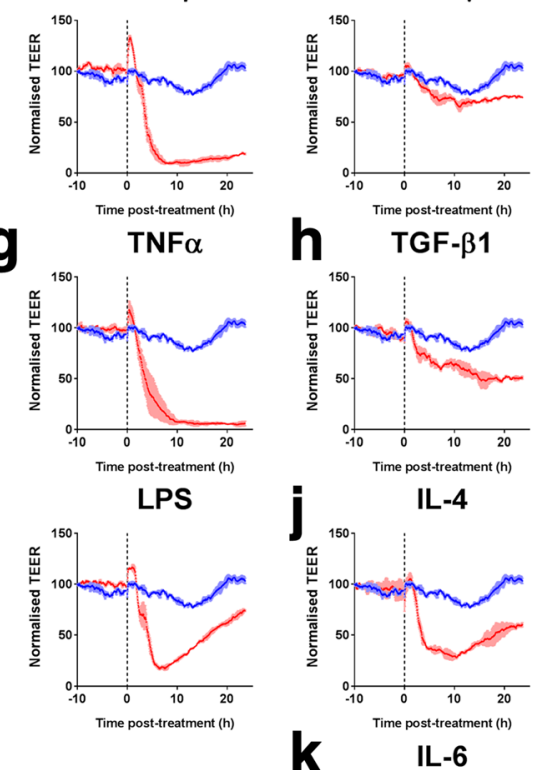

- Vehicle

- Stimulus

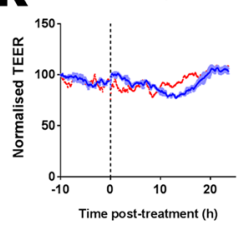

Fig. 6 (See legend on next page.) 
(See figure on previous page.)

Fig. 6 Isolated endothelia generate high transendothelial electrical resistance (TEER), which is reduced by application of cytokines. Endothelia or pericytes were grown on an ECIS array until TEER had plateaued (96-120 h), then treated with either vehicle, IL-1 $\beta$, TNFa, LPS, IFN- $\gamma$, TGF- $\beta_{1}$, IL-4, or IL-6 (10 ng/mL) for a further $24 \mathrm{~h}$ and tight junctions stained by immunocytochemistry. a) Endothelial cultures generate TEER in excess of $35 \Omega . c m 2$ (Mean \pm SEM from 6 independent cases). b) Representative ECIS trace from primary endothelia and pericytes. Dashed lines denote when media was changed. Mean \pm SEM from duplicate wells. c) Representative images of claudin-5 immunostaining in endothelia treated with immunogens. Scale bar $=100 \mu \mathrm{m}$, inset $=5 \mu \mathrm{m}$. d) Maximal change in TEER relative to $10 \mathrm{~h}$ pre-treatment baseline in endothelia treated with inflammatory stimuli. Mean \pm SEM, $n=3-4$ independent experiments across $2-3$ cases. e - k) Representative traces from endothelial cultures treated with inflammatory stimuli (red) overlayed on vehicle-treated endothelia (blue) (mean \pm SEM from duplicate wells). Dashed lines denote the point the treatment was added

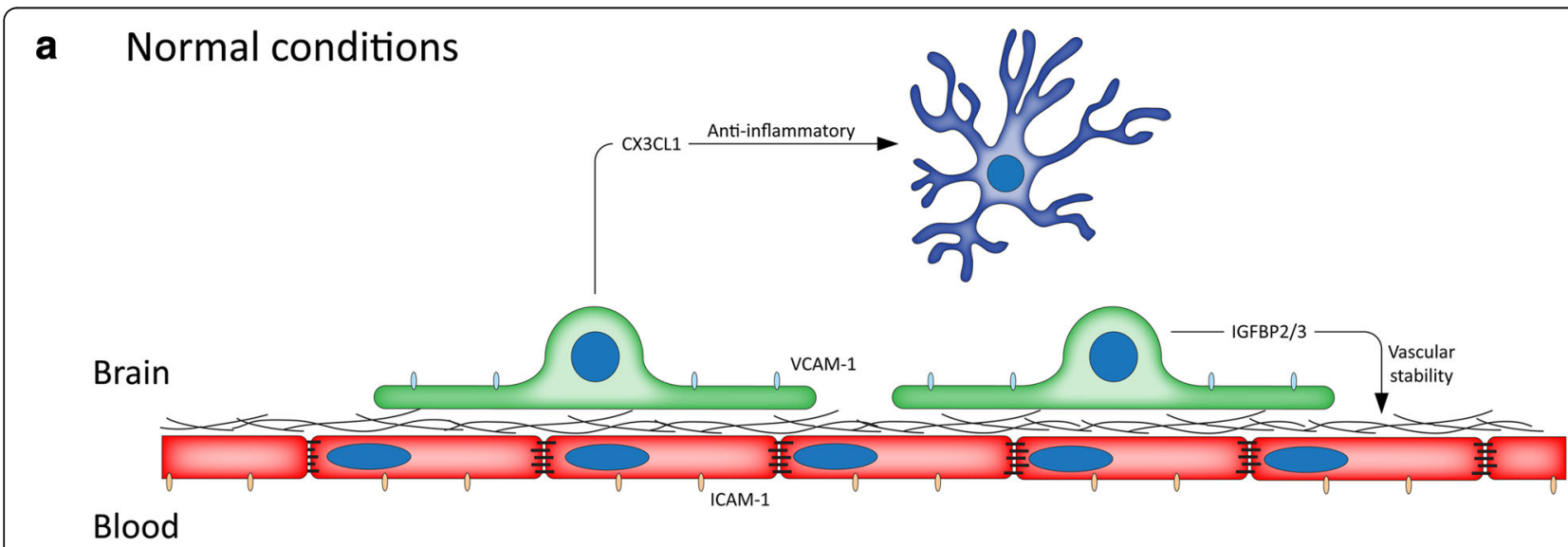

\section{b Inflammation}

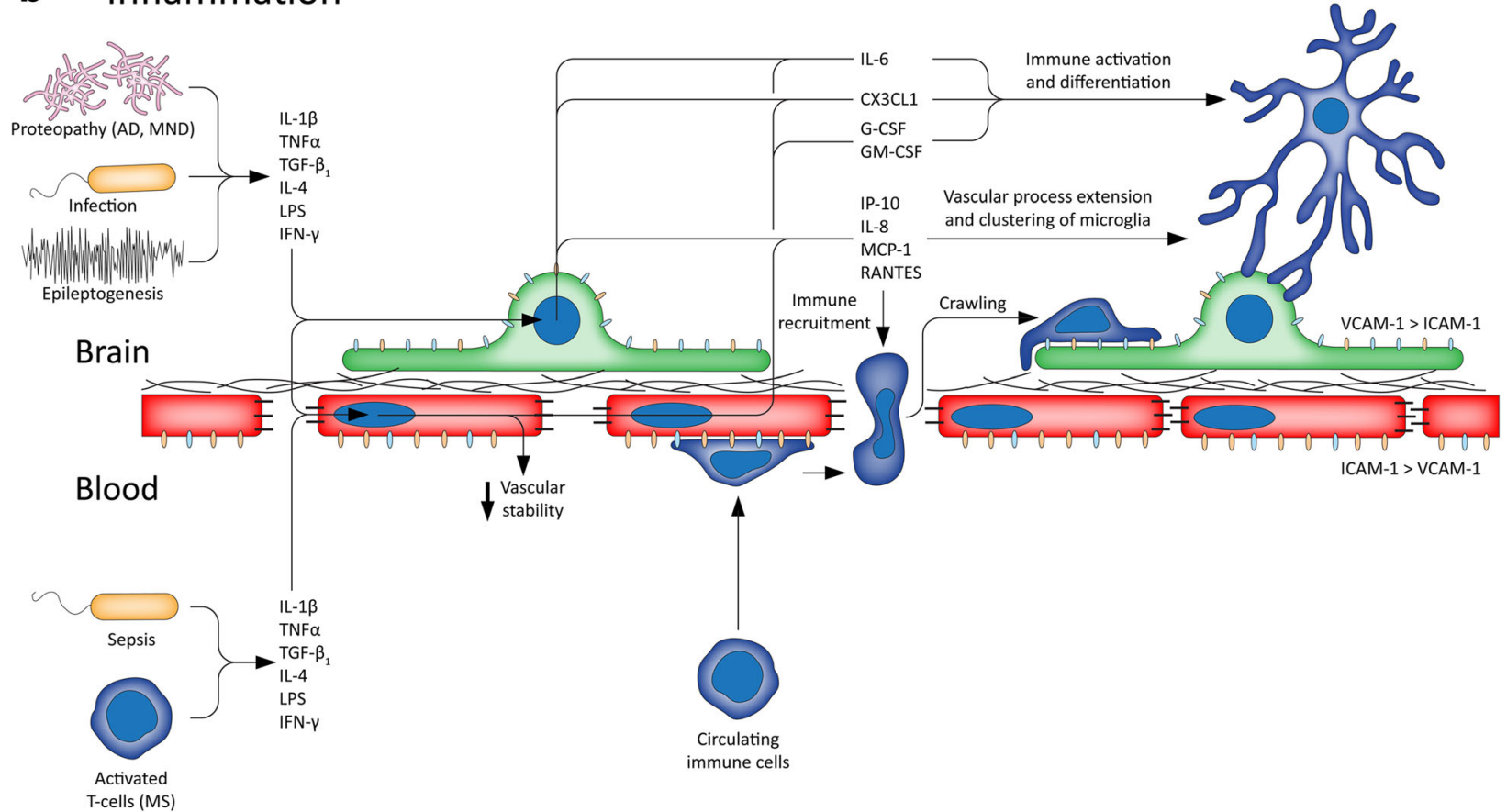

Fig. 7 Contributions of vascular inflammation to neuroinflammatory processes. a Under normal conditions pericyte secretion of CX3CL1 and IGFBP2 and IGFBP3 may be important to the regulation of inflammation and vascular stability. Pericytes basally express low levels of VCAM-1, while endothelia express ICAM-1. b The neurovasculature can be affected by inflammation arising in the brain (e.g. epilepsy, infection, AD) or the periphery (e.g. MS, sepsis). Inflammation disrupts BBB stability by acting on endothelia. Cytokines also activate both pericytes and endothelia to secrete chemoattractants, and upregulate ICAM-1 and VCAM-1 expression. These encourage the recruitment and infiltration of peripheral immune cells through the weakened BBB, where IL-6, CX3CL1, G-CSF, and GM-CSF determine their differentiation and activation. Chemoattractants also encourage the recruitment of microglia and their processes to the vasculature, leading to vascular microglial clustering 
appear to modulate any pathways or secretions in either cell type, nor did it alter barrier function in endothelial cells. Secretion data also indicated that, in general, TNF $\alpha$ was the strongest inducer of inflammatory responses in pericytes, consistent with previous results [61], whereas IL-1 $\beta$ produced the strongest response in endothelia. We found that both endothelia and pericytes could be induced to secrete CX3CL1, although pericytes secreted higher levels of it at baseline. This is potentially important, as the anti-inflammatory action of CX3CL1 is restricted to microglia, which selectively express the receptor CX3CR1 [66]. These data confirm previous reports from our group [56], that pericytes are a source of CX3CL1 in the brain, and here, we show that endothelia are another source of CX3CL1 at the vasculature.

We show here that responses to IL- $1 \beta$, TNF $\alpha$, and LPS through NF- $\mathrm{kB}$ were conserved between cell types, as well as response to IFN- $\gamma$ through STAT1, and to TGF$\beta 1$ through the SMAD2/3 pathway. Despite this, constitutively elevated nuclear SMAD2/3 was observed in endothelia, unlike pericytes, which aligns with the finding that SMAD2/3 is essential to endothelial stability in vivo [67]. Using ECIS, TGF- $\beta_{1}$-mediated disruption of the $\mathrm{BBB}$ was observed, but despite this, we did not observe significant alterations in endothelial secretions. This may be due to technical considerations that were not investigated here, such as the time the secretions were measured, or may represent differences in TGF- $\beta 1$ signalling between the cell types. We hypothesise that differential responses may be due to the endothelialspecific expression of the TGF- $\beta_{1}$ receptor, activin like kinase-1 (ALK1) [68]. ALK1 signals through the SMAD1/5/8 pathway [69] and may alter the outcome of TGF- $\beta_{1}$ treatment.

We found that G-CSF and GM-CSF were highly, and almost exclusively, secreted by endothelia. Both G-CSF and GM-CSF are important cytokines regulating the differentiation, activation, and survival of immune cells [70, 71]. Generally, GM-CSF has been found to promote inflammation [70], while G-CSF has been found to suppress it [72-74]. In situ hybridisation of EAE and IL-1 $\beta$ treated mice has revealed that GM-CSF, IL-6, and G-CSF are expressed at the vasculature, and were found to be upregulated in the conditioned media of stimulated endothelial cells [25]. Interestingly, GM-CSF has previously been shown to enhance monocyte transmigration of endothelia in vitro and increase expression of MHC-II, CD40, TNFa, and reactive oxygen species production [75]. In line with these observations is the recent finding that IL- $1 \beta$ selectively drives G-CSF and GM-CSF expression in endothelia, and that it is required for the transmigration of monocytes in EAE by upregulating CCR2 [24]. Furthermore, IL-1 $\beta$ causes monocytes to differentiate into antigen presenting cells in the perivascular space, priming infiltrating T-cells
[24]. In addition, IL-1 $\beta$ expression by bone marrowresident myeloid cells was required for rodents to develop EAE [24]. This work complements these findings that GCSF and GM-CSF expression is restricted to endothelial cells and highlights the importance of these factors in regulating the transmigration of immune cells. The roles of G-CSF, and many other vascular secretions here, are less well known, and warrant further study.

Results from CBA analysis revealed that IL- $1 \beta$ was the strongest inflammatory stimulus overall, inducing the expression of every secretion measured by cytometric bead array. The difference in IL-1 $\beta$ response in pericytes and endothelia observed using the secretome profiler reinforced CBA data. Secretome profiling also detected that VCAM-1 is constitutively secreted by pericytes, while GM-CSF and G-CSF are strongly secreted by endothelia. Despite this, the majority of secreted factors from endothelia and pericytes were shared, differing only in the level of secretion. Amongst the most highly expressed secretions in both cell types were Serpin E1, GRO- $\alpha$, MIP-3 $\alpha$, CXCL5, IL-8, IL-6, and MCP-1. Both cell types strongly secreted a diverse range of chemoattractants, which corresponds well with the role of the cerebrovasculature in the recruitment of immune cells upon inflammatory insult. These chemoattractants may also be relevant to vascular clustering of microglia $[11,18]$ or microglial process extension following insult [76]. We identified several unique or highly enriched endothelial secretions that were not measured by CBA, including angiopoietin-2, CD31, RAGE, and PDGF-AB/BB. In contrast, pericytes, but not endothelia, secreted high levels of IGFBP-2, and IGFBP-3, something that has not been shown previously. This is particularly interesting, since IGFBPs, especially IGFBP3, have been found to be involved in endothelial viability [77, 78], angiogenesis [79], inflammation, and pericyte coverage [80], as well as being regulated by amyloid- $\beta$ in pericytes [81].

While similarities between endothelial and pericyte inflammatory responses are expected, the differences in responses potentially highlight divergent roles for the two cell types in the regulation of the neurovascular response to inflammation. This study highlights more differences between endothelia and pericytes than have been shown previously [61], as we used a wider range of inflammatory stimuli. We also highlight a number of unique secretions, produced in unstimulated endothelia and pericytes, which may shed light on how pericytes and endothelia regulate signalling at the BBB in different ways. We detected unique secretions in each cell type, representing a unique response to inflammatory stimuli in primary human brain endothelia and pericytes for the first time. A number of these secretions are known to be critical regulators of the immune response in the brain, especially G-CSF, GM-CSF, and CX3CL1. Indeed, it will be important to examine how inflammation shapes the 
interactions of endothelia and pericytes, and how the secretions identified here may shape these. These findings highlight that the cells of the BBB are active players in neuroinflammatory processes. Taken together, these data represent cell type-specific targets in pericytes and endothelia that may be involved in BBB homeostasis, as well as providing further evidence that the neurovasculature is an active player in neuroinflammation (Fig. 7).

\section{Conclusions}

Pericytes and endothelia show unique response profiles in response to a range of inflammatory stimuli and reinforce the active role that the neurovasculature plays in shaping neuroinflammation.

\section{Additional files}

Additional file 1: Supplementary material. Table S1. Case details for tissue used to culture endothelial cells used in this study. Table S2. Case details for pericyte cultures used in this study. Table S3. Specifications of antibodies used in this study. Table S4. Sequences and targets of primers used in this study. Figure S1 Pericyte contamination develops in endothelial cultures in the absence of puromycin selection following cell sorting. Figure S2. Brain endothelial cultures are proliferative and have a proliferative response to VEGF-A. Figure S3. Representative images showing the pathways activated by inflammatory stimuli in pericytes and endothelial cells, quantified in Fig. 3. Figure S4. Inflammatory response of endothelia and pericytes to the inflammatory stimulus panel analysed by immunocytochemistry Figure S5. Brain endothelia generate robust barrier properties in vitro. (DOCX 5909 kb)

Additional file 2: Full secretome profiler dataset from Fig. 5. Pericytes or endothelia from two different cases were treated with either vehicle, or $\mathrm{L}-1 \beta(10 \mathrm{ng} / \mathrm{mL})$ for $24 \mathrm{~h}$ before media were harvested and secretions analysed as per Fig. 5. Values represent intensity measurements from each secretion spot (two spots per secretion) from both biological replicates, from all treatment groups (Vehicle/Pericyte, IL-1 $1 \beta /$ Pericyte, Vehicle/Endothelial, IL-1 $\beta /$ Endothelial). Data are given in an Excel spreadsheet. (XLSX $41 \mathrm{~kb})$

\section{Acknowledgements}

We would like to thank the tissue donors for their generous gift of brain tissue for research. We also thank Lynair Roberts, Peter Bergin, Robyn Oldfield, and the late Marcia Greenaway (staff at Auckland City Hospital) and Marika Eszes (research technician at the New Zealand Human Brain Bank). Additionally, we thank Dr. Scott Graham and Ms. Rebecca Johnson for access to the Accuri C6 flow cytometer which was purchased with support from a Lottery Research Funding Grant (New Zealand) and for assistance with ECIS. This work was supported by a Programme Grant from the Health Research Council of New Zealand and the Hugh Green Foundation.

\section{Funding}

We acknowledge the following funding bodies for their support of this research programme: the Health Research Council of New Zealand, the Sir Thomas and Lady Duncan Trust, the Coker Trust, and the Hugh Green Foundation. The Accuri C6 was partially funded by Lottery Health New Zealand.

\section{Availability of data and materials}

The data presented in this study are included in the manuscript and Additional files 1 and 2. Additional data that are not included can be made available upon reasonable request to the corresponding author.

\section{Authors' contributions}

LS wrote the manuscript. LS, JR, TIHP, and MD designed the experiments. LS performed the majority of experiments. PS, DJ, RJ, PAH, SJO, EWM, RLMF, and
MD all contributed materials and relevant expertise and assisted in the manuscript preparation. All authors have read and approved the final manuscript.

\section{Ethics approval and consent to participate}

Studies undertaken using these tissues were approved by the Northern Regional Ethics Committee (New Zealand), and informed consent was obtained from all donors. All methods were carried out in accordance with the approved guidelines.

\section{Competing interests}

The authors declare that they have no competing interests.

\section{Publisher's Note}

Springer Nature remains neutral with regard to jurisdictional claims in published maps and institutional affiliations.

\section{Author details}

'Department of Pharmacology and Clinical Pharmacology, The University of Auckland, Private Bag 92019, Auckland 1142, New Zealand. ${ }^{2}$ Centre for Brain Research, The University of Auckland, Private Bag 92019, Auckland 1142, New Zealand. ${ }^{3}$ Department of Anatomy and Medical Imaging, The University of Auckland, Private Bag 92019, Auckland 1142, New Zealand. ${ }^{4}$ Auckland City Hospital, Auckland 1023, New Zealand.

Received: 8 February 2018 Accepted: 18 April 2018

Published online: 11 May 2018

\section{References}

1. Rustenhoven J, Jansson D, Smyth LC, Dragunow M. Brain pericytes as mediators of neuroinflammation. Trends Pharmacol Sci. 2017;38(3):291-304.

2. Winkler EA, Bell RD, Zlokovic BV. Central nervous system pericytes in health and disease. Nat Neurosci. 2011;14(11):1398-405.

3. Bechmann I, Galea I, Perry VH. What is the blood-brain barrier (not)? Trends Immunol. 2007;28(1):5-11.

4. Huber JD, Egleton RD, Davis TP. Molecular physiology and pathophysiology of tight junctions in the blood-brain barrier. Trends Neurosci. 2001;24(12): 719-25.

5. Aird WC. Phenotypic heterogeneity of the endothelium. Circ Res. 2007; 100(2):174-90.

6. Tontsch U, Bauer H-C. Glial cells and neurons induce blood-brain barrier related enzymes in cultured cerebral endothelial cells. Brain Res. 1991;539(2): 247-53.

7. Abbott NJ, Rönnbäck L, Hansson E. Astrocyte-endothelial interactions at the blood-brain barrier. Nat Rev Neurosci. 2006;7(1):41.

8. Daneman $R$, Zhou $L$, Kebede AA, Barres BA. Pericytes are required for bloodbrain barrier integrity during embryogenesis. Nature. 2010:468(7323):562-6.

9. Armulik A, Genové G, Mäe M, Nisancioglu MH, Wallgard E, Niaudet C, He L, Norlin J, Lindblom P, Strittmatter K. Pericytes regulate the blood-brain barrier. Nature. 2010;468(7323):557-61.

10. Bonkowski D, Katyshev V, Balabanov RD, Borisov A, Dore-Duffy P. The CNS microvascular pericyte: pericyte-astrocyte crosstalk in the regulation of tissue survival. Fluids Barriers CNS. 2011;8(1):8.

11. Davalos D, Ryu JK, Merlini M, Baeten KM, Le Moan N, Petersen MA, Deerinck TJ, Smirnoff DS, Bedard C, Hakozaki H. Fibrinogen-induced perivascular microglial clustering is required for the development of axonal damage in neuroinflammation. Nat Commun. 2012;3:1227.

12. Zlokovic BV. The blood-brain barrier in health and chronic neurodegenerative disorders. Neuron. 2008;57(2):178-201.

13. Horner PJ, Gage FH. Regeneration in the adult and aging brain. Arch Neurol. 2002:59(11):1717-20.

14. Brown GC, Vilalta A. How microglia kill neurons. Brain Res. 2015;1628:288-97.

15. Block ML, Hong J-S. Microglia and inflammation-mediated neurodegeneration: multiple triggers with a common mechanism. Prog Neurobiol. 2005;76(2):77-98

16. Heppner FL, Ransohoff RM, Becher B. Immune attack: the role of inflammation in Alzheimer disease. Nat Rev Neurosci. 2015;16(6):358-72.

17. Narayan PJ, Kim S-L, Lill C, Feng S, Faull RL, Curtis MA, Dragunow M. Assessing fibrinogen extravasation into Alzheimer's disease brain using high-content screening of brain tissue microarrays. J Neurosci Methods. 2015;247:41-9. 
18. Klement W, Garbelli R, Zub E, Rossini L, Tassi L, Girard B, Blaquiere M, Bertaso F, Perroy J, de Bock F. Seizure progression and inflammatory mediators promote pericytosis and pericyte-microglia clustering at the cerebrovasculature. Neurobiol Dis. 2018;

19. Milesi S, Boussadia B, Plaud C, Catteau M, Rousset M-C, De Bock F, Schaeffer M, Lerner-Natoli M, Rigau V, Marchi N. Redistribution of PDGFR $\beta$ cells and NG2DsRed pericytes at the cerebrovasculature after status epilepticus. Neurobiol Dis. 2014;71:151-8.

20. Fernández-Klett F, Potas JR, Hilpert D, Blazej K, Radke J, Huck J, Engel O, Stenzel W, Genové G, Priller J. Early loss of pericytes and perivascular stromal cell-induced scar formation after stroke. J Cereb Blood Flow Metab. 2013;33(3):428-39.

21. Sakuma R, Kawahara M, Nakano-Doi A, Takahashi A, Tanaka Y, Narita A Kuwahara-Otani S, Hayakawa T, Yagi H, Matsuyama T. Brain pericytes serve as microglia-generating multipotent vascular stem cells following ischemic stroke. J Neuroinflammation. 2016;13(1):57.

22. Frischer JM, Bramow S, Dal-Bianco A, Lucchinetti CF, Rauschka $H_{\text {, }}$ Schmidbauer M, Laursen $H$, Sorensen PS, Lassmann $H$. The relation between inflammation and neurodegeneration in multiple sclerosis brains. Brain. 2009;132(5):1175-89.

23. Dendrou CA, Fugger L, Friese MA. Immunopathology of multiple sclerosis. Nat Rev Immunol. 2015;15(9):545.

24. Paré $A$, Mailhot $B$, Lévesque SA, Juzwik C, Doss PMIA, Lécuyer M-A, Prat $A$ Rangachari M, Fournier A, Lacroix S. IL-1 $\beta$ enables CNS access to CCR2hi monocytes and the generation of pathogenic cells through GM-CSF released by CNS endothelial cells. Proc Natl Acad Sci. 2018;115(6):E1194E1203.

25. Lévesque SA, Paré A, Mailhot B, Bellver-Landete V, Kébir H, Lécuyer M-A, Alvarez JI, Prat A, de Rivero Vaccari JP, Keane RW. Myeloid cell transmigration across the CNS vasculature triggers $\mathrm{LL}-1 \beta$-driven neuroinflammation during autoimmune encephalomyelitis in mice. J Exp Med. 2016;213(6):929-49.

26. Grammas P. Neurovascular dysfunction, inflammation and endothelial activation: implications for the pathogenesis of Alzheimer's disease J Neuroinflammation. 2011;8(1):26.

27. Zhao Z, Nelson AR, Betsholtz C, Zlokovic BV. Establishment and dysfunction of the blood-brain barrier. Cell. 2015;163(5):1064-78.

28. Zhou T, Zhao L, Zhan $R$, He Q, Tong $Y$, Tian X, Wang H, Zhang T, Fu Y, Sun $Y$. Blood-brain barrier dysfunction in mice induced by lipopolysaccharide is attenuated by dapsone. Biochem Biophys Res Commun. 2014;453(3):419-24

29. Varatharaj A, Galea I. The blood-brain barrier in systemic inflammation. Brain Behav Immun. 2017:60:1-12.

30. Varvel NH, Neher JJ, Bosch A, Wang W, Ransohoff RM, Miller RJ, Dingledine R. Infiltrating monocytes promote brain inflammation and exacerbate neuronal damage after status epilepticus. Proc Natl Acad Sci. 2016;113(38): E5665-74

31. Montagne A, Barnes SR, Sweeney MD, Halliday MR, Sagare AP, Zhao Z, Toga AW, Jacobs RE, Liu CY, Amezcua L. Blood-brain barrier breakdown in the aging human hippocampus. Neuron. 2015;85(2):296-302.

32. Halliday MR, Rege SV, Ma Q, Zhao Z, Miller CA, Winkler EA, Zlokovic BV. Accelerated pericyte degeneration and blood-brain barrier breakdown in apolipoprotein E4 carriers with Alzheimer's disease. J Cereb Blood Flow Metab. 2016;36(1):216-27.

33. Xanthos DN, Sandkühler J. Neurogenic neuroinflammation: inflammatory CNS reactions in response to neuronal activity. Nat Rev Neurosci. 2014;15(1):43.

34. Yao Y, Tsirka SE. Monocyte chemoattractant protein-1 and the blood-brain barrier. Cell Mol Life Sci. 2014;71(4):683-97.

35. Vestweber D. How leukocytes cross the vascular endothelium. Nat Rev Immunol. 2015;15(11):692.

36. Jansson D, Rustenhoven J, Feng S, Hurley D, Oldfield RL, Bergin PS, Mee EW Faull RL, Dragunow M. A role for human brain pericytes in neuroinflammation. J Neuroinflammation. 2014;11(1):104.

37. Kovac A, Erickson MA, Banks WA. Brain microvascular pericytes are immunoactive in culture: cytokine, chemokine, nitric oxide, and LRP-1 expression in response to lipopolysaccharide. J Neuroinflammation. 2011; $8(1): 139$.

38. Jansson D, Scotter EL, Rustenhoven J, Coppieters N, Smyth LC, Oldfield RL, Bergin PS, Mee EW, Graham ES, Faull RL. Interferon- $\gamma$ blocks signalling through PDGFRß in human brain pericytes. J Neuroinflammation. 2016;13(1):249.

39. Stark K, Eckart A, Haidari S, Tirniceriu A, Lorenz M, von Brühl M-L, Gärtner F, Khandoga AG, Legate KR, Pless R. Capillary and arteriolar pericytes attract innate leukocytes exiting through venules and 'instruct' them with patternrecognition and motility programs. Nat Immunol. 2013;14(1):41-51.

40. Proebstl D, Voisin M-B, Woodfin A, Whiteford J, D'Acquisto F, Jones GE, Rowe D, Nourshargh S. Pericytes support neutrophil subendothelial cell crawling and breaching of venular walls in vivo. J Exp Med. 2012;209(6):1219-234.

41. Wang S, Cao C, Chen Z, Bankaitis V, Tzima E, Sheibani N, Burridge K. Pericytes regulate vascular basement membrane remodeling and govern neutrophil extravasation during inflammation. PLoS One. 2012;7(9):e45499.

42. Dohgu S, Banks WA. Brain pericytes increase the lipopolysaccharideenhanced transcytosis of HIV-1 free virus across the in vitro blood-brain barrier: evidence for cytokine-mediated pericyte-endothelial cell crosstalk. Fluids Barriers CNS. 2013;10(1):23.

43. Underly RG, Levy M, Hartmann DA, Grant RI, Watson AN, Shih AY. Pericytes as inducers of rapid, matrix metalloproteinase-9-dependent capillary damage during ischemia. J Neurosci. 2017:37(1):129-40.

44. Dias DO, Kim H, Holl D, Solnestam BW, Lundeberg J, Carlén M, Göritz C, Frisén J. Reducing pericyte-derived scarring promotes recovery after spinal cord injury. Cell. 2018;173(1):153-65.

45. Göritz C, Dias DO, Tomilin N, Barbacid M, Shupliakov O, Frisén J. A pericyte origin of spinal cord scar tissue. Science. 2011;333(6039):238-42.

46. Helms HC, Abbott NJ, Burek M, Cecchelli R, Couraud P-O, Deli MA, Förster C Galla HJ, Romero IA, Shusta EV. In vitro models of the blood-brain barrier: an overview of commonly used brain endothelial cell culture models and guidelines for their use. J Cereb Blood Flow Metab. 2016;36(5):862-90.

47. Dragunow M. The adult human brain in preclinical drug development. Nat Rev Drug Discov. 2008;7(8):659-66.

48. Gibbons HM, Hughes SM, Van Roon-Mom W, Greenwood JM, Narayan PJ, Teoh HH, Bergin PM, Mee EW, Wood PC, Faull RL, et al. Cellular composition of human glial cultures from adult biopsy brain tissue. J Neurosci Methods. 2007;166(1):89-98.

49. Rustenhoven J, Park TI, Schweder P, Scotter J, Correia J, Smith AM, Gibbons HM, Oldfield RL, Bergin PS, Mee EW, et al. Isolation of highly enriched primary human microglia for functional studies. Sci Rep. Rep. 2016;6:19371.

50. Park TI-H, Monzo H, Mee EW, Bergin PS, Teoh HH, Montgomery JM, Faull RL, Curtis MA, Dragunow M. Adult human brain neural progenitor cells (NPCs) and fibroblast-like cells have similar properties in vitro but only NPCs differentiate into neurons. PLoS One. 2012;7(6):e37742.

51. Paul G, Özen I, Christophersen NS, Reinbothe T, Bengzon J, Visse E, Jansson K, Dannaeus K, Henriques-Oliveira C, Roybon L. The adult human brain harbors multipotent perivascular mesenchymal stem cells. PLoS One. 2012; 7(4):e35577.

52. Rustenhoven J, Scotter EL, Jansson D, Kho DT, Oldfield RL, Bergin PS, Mee EW, Faull RL, Curtis MA, Graham SE, et al. An anti-inflammatory role for C/ EBPS in human brain pericytes. Sci Rep. 2015;5

53. Perriere N, Demeuse P, Garcia E, Regina A, Debray M, Andreux JP, Couvreur P, Scherrmann JM, Temsamani J, Couraud PO. Puromycin-based purification of rat brain capillary endothelial cell cultures. Effect on the expression of blood-brain barrier-specific properties. J Neurochem. 2005;93(2):279-89.

54. Giaever I, Keese CR. Micromotion of mammalian cells measured electrically. Proc Natl Acad Sci. 1991;88(17):7896-900.

55. Ruck T, Bittner S, Epping L, Herrmann AM, Meuth SG. Isolation of primary murine brain microvascular endothelial cells. JoVE. 2014;93:e52204.

56. Rustenhoven J, Aalderink M, Scotter EL, Oldfield RL, Bergin PS, Mee EW, Graham ES, Faull RL, Curtis MA, Park TI, et al. TGF-beta1 regulates human brain pericyte inflammatory processes involved in neurovasculature function. J Neuroinflammation. 2016;13(1):1.

57. Mach F, Schönbeck U, Sukhova GK, Bourcier T, Bonnefoy J-Y, Pober JS, Libby $P$. Functional CD40 ligand is expressed on human vascular endothelial cells, smooth muscle cells, and macrophages: implications for CD40-CD40 ligand signaling in atherosclerosis. Proc Natl Acad Sci. 1997;94(5):1931-6.

58. Park TI, Feisst V, Brooks AE, Rustenhoven J, Monzo HJ, Feng SX, Mee EW Bergin PS, Oldfield R, Graham ES. Cultured pericytes from human brain show phenotypic and functional differences associated with differential CD90 expression. Sci Rep. 2016:6

59. Rustenhoven J, Smyth LC, Jansson D, Schweder P, Aalderink M, Scotter EL, Mee EW, Faull RL, Park TI-H, Dragunow M. Modelling physiological and pathological conditions to study pericyte biology in brain function and dysfunction. BMC Neurosci. 2018;19(1):6.

60. Sweeney MD, Sagare AP, Zlokovic BV. Blood-brain barrier breakdown in Alzheimer disease and other neurodegenerative disorders. Nat Rev Neurol. 2018;14(3):133-50 
61. Matsumoto J, Takata F, Machida T, Takahashi H, Soejima Y, Funakoshi M, Futagami K, Yamauchi A, Dohgu S, Kataoka Y. Tumor necrosis factor-astimulated brain pericytes possess a unique cytokine and chemokine release profile and enhance microglial activation. Neurosci Lett. 2014;578:133-8.

62. Banks WA, Kovac A, Morofuji Y. Neurovascular unit crosstalk: Pericytes and astrocytes modify cytokine secretion patterns of brain endothelial cells. J Cereb Blood Flow Metab. 2017. https://doi.org/10.1177/0271678X17740793.

63. O'Carroll SJ, Kho DT, Wiltshire R, Nelson V, Rotimi O, Johnson R, Angel CE, Graham ES. Pro-inflammatory TNFa and IL-1 $\beta$ differentially regulate the inflammatory phenotype of brain microvascular endothelial cells. J Neuroinflammation. 2015;12(1):1.

64. Gadani SP, Cronk JC, Norris GT, Kipnis J. IL-4 in the brain: a cytokine to remember. J Immunol. 2012;189(9):4213-9.

65. Friedrich K, Kammer W, Erhardt I, Brändlein S, Sebald W, Moriggl R. Activation of STAT5 by IL-4 relies on Janus kinase function but not on receptor tyrosine phosphorylation, and can contribute to both cell proliferation and gene regulation. Int Immunol. 1999;11(8):1283-94.

66. Cardona AE, Pioro EP, Sasse ME, Kostenko V, Cardona SM, Dijkstra IM, Huang D, Kidd G, Dombrowski S, Dutta R. Control of microglial neurotoxicity by the fractalkine receptor. Nat Neurosci. 2006;9(7):917.

67. Itoh F, Itoh S, Adachi T, Ichikawa K, Matsumura Y, Takagi T, Festing M, Watanabe T, Weinstein M, Karlsson S. Smad2/Smad3 in endothelium is indispensable for vascular stability via S1PR1 and N-cadherin expressions. Blood. 2012;119(22):5320-8.

68. Oh SP, Seki T, Goss KA, Imamura T, Yi Y, Donahoe PK, Li L, Miyazono K, ten Dijke $P$, Kim S. Activin receptor-like kinase 1 modulates transforming growth factor- $\beta 1$ signaling in the regulation of angiogenesis. Proc Natl Acad Sci. 2000;97(6):2626-31.

69. Goumans MJ, Valdimarsdottir $G$, Itoh $S$, Rosendahl A, Sideras $P$, ten Dijke $P$. Balancing the activation state of the endothelium via two distinct TGF- $\beta$ type I receptors. EMBO J. 2002;21(7):1743-53.

70. Ushach I, Zlotnik A. Biological role of granulocyte macrophage colonystimulating factor (GM-CSF) and macrophage colony-stimulating factor (MCSF) on cells of the myeloid lineage. J Leukoc Biol. 2016;100(3):481-9.

71. Schuster A, Klotz M, Schwab T, Lilischkis R, Schneider A, Schäfer K-H. Granulocyte-colony stimulating factor: a new player for the enteric nervous system. Cell Tissue Res. 2014;355(1):35-48.

72. Jellema RK, Passos VL, Ophelders DR, Wolfs TG, Zwanenburg A, De Munter S, Nikiforou M, Collins JJ, Kuypers E, Bos GM. Systemic G-CSF attenuates cerebral inflammation and hypomyelination but does not reduce seizure burden in preterm sheep exposed to global hypoxia-ischemia. Exp Neurol. 2013:250:293-303.

73. Jiang H, Liu C, Feng J, Wang P, Zhao C, Xie Z, Wang Y, Xu S, Zheng C, Bi J. Granulocyte colony-stimulating factor attenuates chronic neuroinflammation in the brain of amyloid precursor protein transgenic mice: an Alzheimer's disease mouse model. J Int Med Res. 2010;38(4):1305-12.

74. Li L, McBride DW, Doycheva D, Dixon BJ, Krafft PR, Zhang JH, Tang J. G-CSF attenuates neuroinflammation and stabilizes the blood-brain barrier via the PI3K/Akt/GSK-3ß signaling pathway following neonatal hypoxia-ischemia in rats. Exp Neurol. 2015;272:135-44.

75. Vogel D, Kooij G, Heijnen PD, Breur M, Peferoen LA, Valk P, Vries HE, Amor S, Dijkstra CD. GM-CSF promotes migration of human monocytes across the blood brain barrier. Eur J Immunol. 2015:45(6):1808-19.

76. Lou N, Takano T, Pei Y, Xavier AL, Goldman SA, Nedergaard M. Purinergic receptor P2RY12-dependent microglial closure of the injured blood-brain barrier. Proc Natl Acad Sci. 2016;113(4):1074-9.

77. Kielczewski JL, Jarajapu YP, McFarland EL, Cai J, Afzal A, Calzi SL, Chang KH, Lydic T, Shaw LC, Busik J. Insulin-like growth factor binding protein-3 mediates vascular repair by enhancing nitric oxide generation. Circ Res. 2009;105(9):897-905.

78. Zhang Q, Jiang Y, Miller MJ, Peng B, Liu L, Soderland C, Tang J, Kern TS, Pintar J, Steinle JJ. IGFBP-3 and TNF-a regulate retinal endothelial cell Apoptosis/GFBP-3 regulates retinal endothelial cell apoptosis. Invest Ophthalmol Vis Sci. 2013;54(8):5376-84

79. Lofqvist C, Chen J, Connor KM, Smith AC, Aderman CM, Liu N, Pintar JE, Ludwig T, Hellstrom A, Smith LE. IGFBP3 suppresses retinopathy through suppression of oxygen-induced vessel loss and promotion of vascular regrowth. Proc Natl Acad Sci. 2007;104(25):10589-94.

80. Kielczewski JL, Hu P, Shaw LC, Calzi SL, Mames RN, Gardiner TA, McFarland E, Chan-Ling T, Grant MB. Novel protective properties of IGFBP-3 result in enhanced pericyte ensheathment, reduced microglial activation, increased microglial apoptosis, and neuronal protection after ischemic retinal injury. Am J Pathol. 2011;178(4):1517-28.

81. Rensink A, Otte-Höller I, Ten Donkelaar H, De Waal R, Kremer B, Verbeek M. Differential gene expression in human brain pericytes induced by amyloid- $\beta$ protein. Neuropathol Appl Neurobiol. 2004;30(3):279-91.

\section{Ready to submit your research? Choose BMC and benefit from:}

- fast, convenient online submission

- thorough peer review by experienced researchers in your field

- rapid publication on acceptance

- support for research data, including large and complex data types

- gold Open Access which fosters wider collaboration and increased citations

- maximum visibility for your research: over $100 \mathrm{M}$ website views per year

At BMC, research is always in progress.

Learn more biomedcentral.com/submissions 